\author{
ALFREDO LÓPEZ AUSTIN \\ INSTITUTO DE INVESTIGACIONES ANTROPOLÓGICAS, UNAM
}

\title{
Mitos e íconos \\ de la ruptura del Eje Cósmico: \\ Un glifo toponímico de las piedras de Tizoc $y$ del Ex-Arzobispado
}

El mito, el ícono y el nacimiento de los ciclos

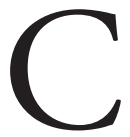

OMO HISTORIADORES DE LA TRADICIÓN religiosa mesoamericana debemos explorar las distintas formas de expresión de la antigüedad, tendiendo entre ellas los lazos que permitan potenciar los resultados del estudio. Obviamente uno de los más productivos, es el lazo que se tiende entre la iconografía y la mitología. Tanto las representaciones visuales como las creencias y la narrativa míticas pertenecen a campos de acción específicos y están regidas por normas particulares de producción, pero todas ellas surgen de la misma fuente —el macrosistema que llamamos cosmovisión — y se vinculan permanentemente en el ejercicio social.

En diferentes trabajos he abordado el tema del apoyo recíproco entre imagen visual y mito. En algunos he formulado recomendaciones y reglas que he considerado útiles para la investigación conjunta. Una de dichas recomendaciones tiene que ver con la necesidad de distinguir en la iconografía mesoamericana entre los íconos que remiten a la percepción sensorial de un objeto y los que apuntan a la aprehensión conceptual del mismo. ${ }^{\mathrm{I}}$ Los primeros se refieren a la

I. Alfredo López Austin, "Ícono y mito, su convergencia", Ciencias, México, Universidad Nacional Autónoma de México-Facultad de Ciencias, núm. 74, abril-junio de 2004, pp. 4-15. 
apariencia visual atribuible a un objeto, independientemente de su naturaleza real o imaginaria. Los segundos, en cambio, se refieren a los atributos del objeto: derivan de su representación mental. Así, al representarse una figura cósmica (como puede serlo el plano terrestre) por medio de la escultura o la pintura, no se "muestra" la apariencia del objeto representado, sino que se lo "describe" a partir de algunas de sus características conceptuales. En esta "descripción" conceptual, se eligen algunos de los elementos calificadores entre un abundante repertorio de atributos; en la mayoría de los casos, la elección debe suponerse adecuada al mensaje que se desea transmitir.

El ejemplo que utilicé en el trabajo aludido fue el de la figura del Árbol Cósmico, cuyas representaciones variaban de acuerdo con lo que de él se quería comunicar: árbol florido, árbol con marcada división longitudinal, cuerpo de cocodrilo que adquiere forma arbórea, cruz, árbol con listados diagonales de bandas de colores, ceiba de tronco hinchado, planta de maíz, cuerpo sangrante, cuerpo tronchado, tronco compuesto por dos ramales que giran helicoidalmente alrededor de un eje, etc. Una figura del Árbol Cósmico con todos sus calificadores sería, si no imposible, al menos excesiva e inútil, puesto que el mensaje adquiriría una complejidad innecesaria.

¿Por qué las figuras cósmicas tienen tal abundancia de calificadores? Porque responden simultáneamente a principios nomológicos y a funciones cósmicas específicas. En su sentido más abstracto, representan una ley divina general; en contraste, señalan con sus múltiples calificadores cada una de sus operaciones en la dinámica del universo.

Pongamos por caso el Eje Cósmico. Éste es, fundamentalmente, el motor del universo. A partir de esta función genérica, el Eje adquiere sus calificadores específicos y, con cada uno de ellos, sus representaciones mentales y las imágenes de distintos tipos que las expresan: verbales, visuales, musicales, etc. Las funciones y los calificadores se multiplican al particularizarse y convertirse en explicaciones más precisas de los entes y los procesos del universo. Así, por ejemplo, debido a que el movimiento cósmico requiere de la oposición de contrarios, el eje adquirirá como calificador la condición de enlace de los principios opuestos (v.g. la capacidad de unir lo alto y lo bajo) o la de ámbito de confluencia de las fuerzas contrarias (v.g. su constitución como cuerpo formado por fuego y agua). Con cada una de estas especificaciones aumentarán sus imágenes, en un curso creciente de precisión de los calificadores.

En este artículo elijo como figura, precisamente, el Eje Cósmico. Particularizo su imagen con base en una de sus calificaciones. Parto del enunciado de una ley 
divina: existe un flujo ininterrumpido entre el anecúmeno y el ecúmeno ${ }^{2}$ debido a que todo lo que existe en este mundo debe ser alimentado cíclicamente desde el ámbito de los dioses.

En principio, el flujo cíclico es un movimiento que se produce a través del Eje Cósmico. ${ }^{3}$ Sin embargo, el complejo sistema de circulación implica la existencia de segmentos funcionales. Éstos pueden ser representados por una secuencia de tres figuras en que se divide la principal: a) abajo, un inframundo frío, lugar de la muerte; b) sobre éste, una bodega en la que se guarda la sustancia sutil que alimenta al mundo, o sea el Monte Sagrado, y c) en la cúspide del monte, el Árbol Florido, segmento distribuidor de la riqueza. ${ }^{4}$ Sin embargo, en muchas ocasiones una parte expresa el todo. La flexibilidad de las expresiones permite que, como sinécdoque inductiva, las simples figuras del Árbol o del Monte puedan representar la figura total del Eje. ${ }^{5}$

Según la cosmovisión mesoamericana, el flujo entre el anecúmeno y el ecúmeno no era eterno: tuvo su origen en la dimensión del mito. El inicio de la corriente dio lugar al nuevo tiempo y al nuevo espacio, el aquí-ahora del ecúmeno. El tránsito creador se marcó con tres fases: a) el encierro primigenio, cuando la riqueza estaba contenida en el allá-entonces, en el tiempo-espacio de los dioses; b) la aventura mítica que abrió con violencia un portal de comunicación entre el anecúmeno y el ecúmeno, y c) el flujo que inició el movimiento cíclico permanente para inundar el ecúmeno con los bienes y los males divinos.

La figura central, además, completó la geometría del cosmos: el Eje se proyectó hacia los cuatro rumbos para convertirse en los cuatro soportes del cielo.

2. Uso el término ecúmeno en el sentido de ámbito del cosmos ocupado por las criaturas, pero también poblado por los entes sobrenaturales. Lo opongo al término anecúmeno como la parte reservada a los sobrenaturales.

3. Propiamente debe decirse que, según el pensamiento mesoamericano, los ciclos cósmicos se producen a través del Eje y de sus proyecciones.

4. Este tema, expuesto aquí en forma tan sintética, lo hemos desarrollado ampliamente Leonardo López Luján y yo en un libro que ha sido entregado para su publicación: Monte SagradoTemplo Mayor (en prensa).

5. En un artículo publicado anteriormente en esta revista (Michel Graulich, "El simbolismo del Templo Mayor de México y sus relaciones con Cacaxtla y Teotihuacan”, Anales del Instituto de Investigaciones Estéticas, México, Universidad Nacional Autónoma de México-Instituto de Investigaciones Estéticas, vol. XXIII, núm. 79, 200I, pp. 5-28), el autor pone en duda la centralidad del Árbol y su subsistencia como elemento cósmico tras su ruptura mítica. Rebatimos sus propuestas en Alfredo López Austin y Leonardo López Luján, Monte Sagrado..., op. cit. 
Cada una de sus réplicas, a su vez, se rompió para dar lugar a procesos cíclicos más complejos y puntuales, todos los que requieren que los flujos circulen ordenadamente desde determinado rumbo del plano terrestre. El ejemplo más claro es el curso del tiempo cotidiano, que hace necesaria la aparición de cada día por uno de los cuatro soportes del cielo en una sucesión levógira.

Como puede suponerse, son muchas las formas de especificar mítica e iconográficamente la violenta apertura de los portales. El movimiento puede referirse, a partir del mismo principio cósmico, a los ciclos de la vida y de la muerte, del movimiento astral, del flujo del tiempo, del surgimiento de los mantenimientos, de las transformaciones meteóricas, etc. Se multiplican así los mitos que responden a cada justificación de existencia mundana y se reproducen las versiones de cada relato prodigioso. Otro tanto ocurrirá con las imágenes visuales, que expresarán con variada gama de motivos los tres tiempos del arranque del mundo. En los mitos, los dioses desgajarán las ramas o cortarán las flores del árbol sagrado; el pájaro carpintero romperá la peña que guarda al Sol en forma de huevo estrellado; el rayo romperá la peña en cuyo interior se encierra el maíz; el tlacuache cruzará el portal con el fuego robado; el gran árbol caerá hecho pedazos debido al extremo peso de sus frutos... En la pintura y la escultura, la imagen del cocodrilo se encontrará como raíz del árbol; la ceiba hinchada mostrará una vulva; la montaña transparentará los siete úteros y su desembocadura; el árbol sangrará por su rama cortada, por la perforación de su tronco herido o por su cuerpo tronchado... Más allá de íconos y mitos, en el paisaje se descubrirán los portales en las bocas de las cuevas o en la superficie rugosa de las piedras que fueron calcinadas por la primera aparición del Sol... Y en la otra geometría, la invisible, el hombre creerá percibir cuatro grandes clases de seres en su entorno, división producida cuando el Eje se proyectó hacia los cuatro rumbos para formar los cuatro sostenes del cielo.

Milagrosamente, cada día surgirán los astros en el horizonte, brotarán las aguas de los manantiales, surgirán las nubes del fondo de las cuevas, germinarán las semillas, parirán las mujeres, y en cada caso se reproducirán las rupturas míticas: las del Eje y las de sus cuatro proyecciones, las del terrón de la milpa o las de las fuentes de las mujeres preñadas. Los ciclos se mantienen gracias a la violencia que abre tanto los portales por los que brota la riqueza como aquéllos por los que ésta es absorbida cuando abandona los cuerpos muertos, después de haber cumplido su misión sobre la Tierra. 


\section{Un extraño glifo toponímico ${ }^{6}$}

Centro ahora mi atención en la naturaleza mítica de un glifo. Reconozco que el tema se ha inscrito en una discusión más amplia, tanto histórica como arqueológica. Sin pretender abordar puntualmente el problema mayor, me refiero a él en los puntos que son pertinentes a mi trabajo. La discusión arranca de dos espectaculares descubrimientos y ha alimentado debates que, a partir de los primeros estudios, rebasan ya los dos siglos.

El primer descubrimiento data del 17 de diciembre de 179I, cuando en la Plaza Mayor de la ciudad de México se abría una zanja para una atarjea, cerca del cementerio de la catedral. ${ }^{7}$ Antonio de Léon y Gama, después de haberse referido en forma pormenorizada a los monumentos hoy conocidos como Piedra del Sol y Coatlicue en su clásica Descripción histórica y cronológica de las dos piedras..., pasa a relatar los hallazgos posteriores, entre los que destaca el del monolito llamado al presente Piedra de Tízoc (figs. I y 2). El sabio se refirió a la forma y tamaño de la escultura como "un cilindro perfectamente fabricado, cuya base tiene de diámetro tres varas castellanas, una pulgada, y cuatro y media líneas, y su altura una vara y una pulgada" ${ }^{8}$

Aquella obra escultórica era en verdad admirable. Se conjugaban en ella el enorme tamaño, la forma peculiar, la finura de su labra, la cantidad de inscripciones que prácticamente cubrían toda su cara superior y la redondez de la lateral y, como una singularidad desconcertante, un profundo canal irregular

6. Uso el término glifo y no jeroglífico (el registrado por la Real Academia Española) para dejar claro el sentido primario de la palabra y su carácter de sustantivo. Reservo al término jeroglífico su carácter de adjetivo y su sentido de símbolo sacro o sacerdotal. En cuanto al segundo término, distingo topónimo como sustantivo de toponímico como adjetivo.

7. Antonio de León y Gama, Descripción histórica y cronológica de las dos piedras, que con ocasión del nuevo empedrado que se está formando en la Plaza principal de México se hallaron en ella el año de 1790, ed. facs., 2a. parte (México, Imprenta del ciudadano Alejandro Valdés, I832), México, Instituto Nacional de Antropología e Historia, 1990, p. 46; Eduard Seler, "Excavations at the Site of the Principal Temple in Mexico", en Collected Works in Mesoamerican Linguistics and Archaeology, 2a. ed., Culver City-Lancaster, California, Labyrinthos, I992, vol. III, pp. I3I y 191, n. 53, especifica que la obra de la atarjea se hacía "a través de la pequeña plaza llamada Empedradillo, antiguamente Placeta del Marqués, y con anterioridad una esquina de la pared del cementerio de la antigua Catedral". Véase también Manuel Orozco y Berra, "El cuauhxicalli de Tízoc", Anales del Museo Nacional de México, vol. I, época I, I877, p. I6.

8. León y Gama, op. cit., p. 46. Las medidas de la pieza son $2.65 \mathrm{~m}$ de diámetro y .94 m de altura. 


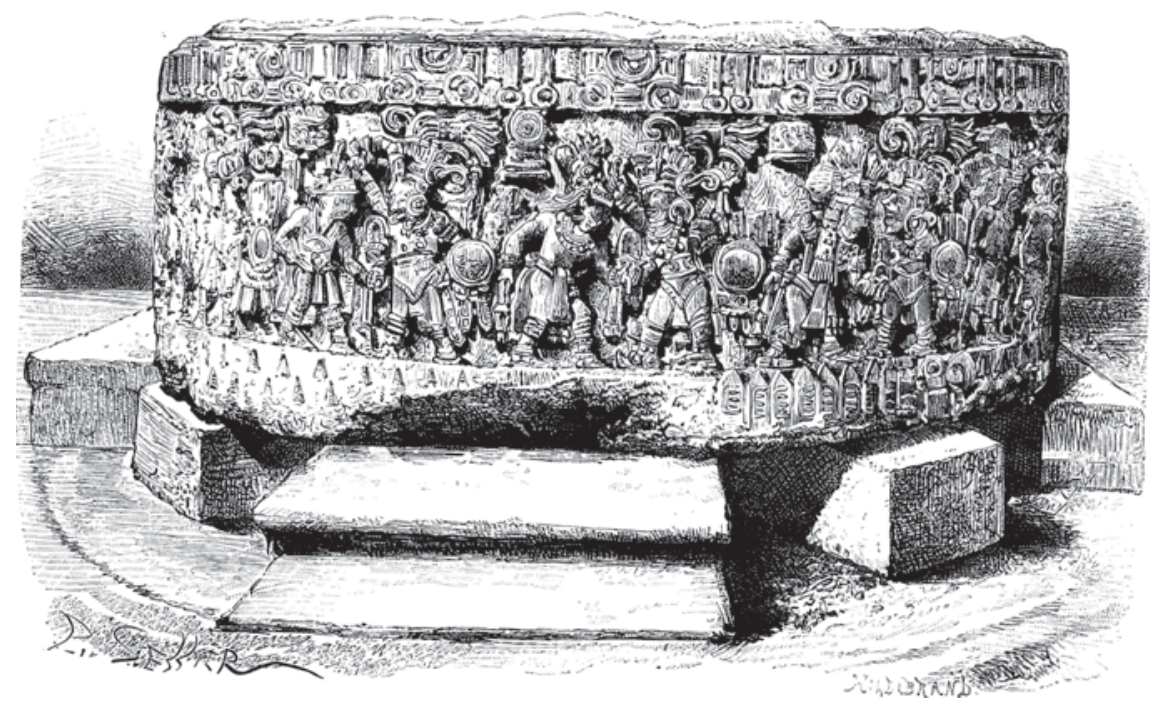

I. La Piedra de Tízoc, según un grabado de Barclay, publicado por Désiré Charnay en Les anciennes villes du Noveau Monde, voyages d'explorations au Mexique et dans l'Amerique Centrale, I857-I882, París, Hachette \& cie., I885, p. 43.

que partía del centro de la cara plana, recorría radialmente su superficie y bajaba verticalmente, dañando las formas geométricas y la integridad de una de las escenas talladas en la piedra. ${ }^{9}$

En el plano horizontal aparecían los rayos del disco solar, que fue inmediatamente identificado por los estudiosos. En la cara vertical había tres franjas: una celeste en el borde superior, otra terrestre en el inferior y, en el amplio centro, la sucesión de quince escenas, en las cuales, en forma repetitiva, un guerrero ricamente ataviado tomaba a un prisionero - un contrincante cubierto tam-

9. Pronto se atribuyó al canal una función ritual, al decirse que estaba hecho para que corriera por él la sangre de los sacrificados. Véase la opinión contraria de León y Gama, op. cit., p. 47. La antigüedad del canal se pone de manifiesto al aparecer dibujado en la obra de Bernardino de Sahagún, Códice florentino. Manuscrito 218-20 de la Colección Palatina de la Biblioteca Medicea Laurenziana, ed. facs., 3 vols., México, Secretaría de Gobernación-Archivo General de la Nación, I979, lib. IX, f. 7r. El dibujo muestra el canal en contexto ritual, pero su efecto destructivo en la talla de la escultura es tal que puede suponerse que es del inicio de la colonia y que la representación pictográfica contiene un anacronismo. 


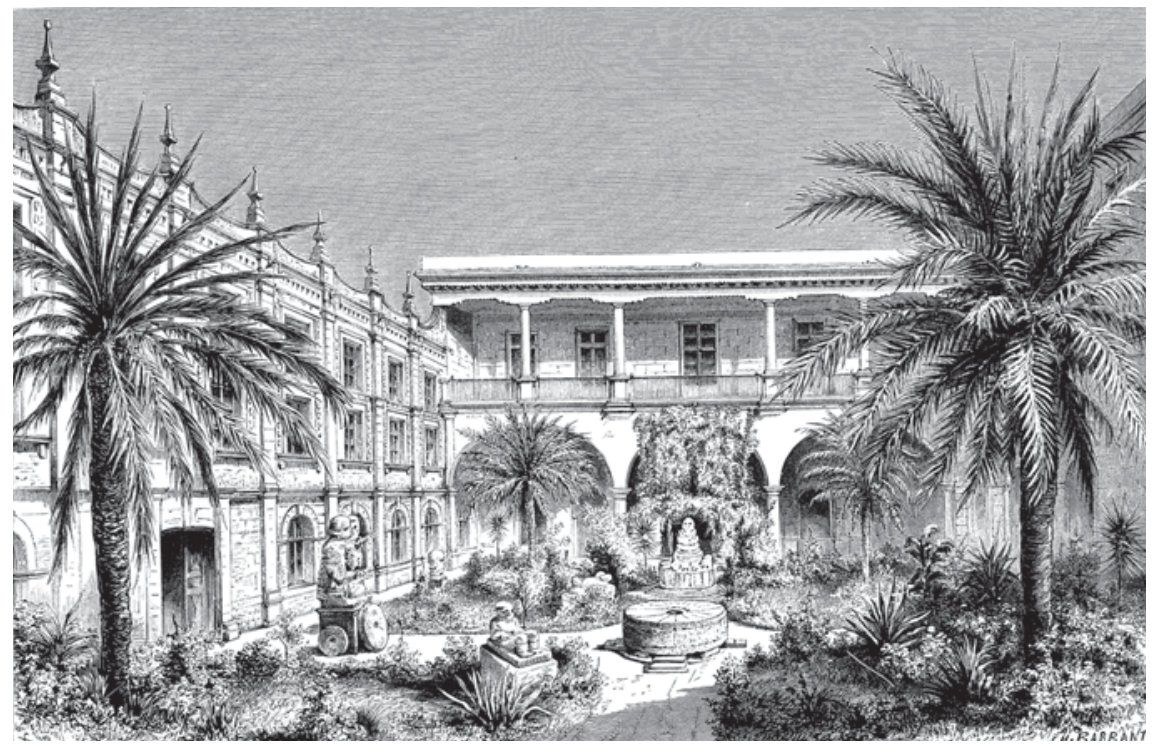

2. La Piedra de Tízoc en el patio del Museo Nacional de Antropología de la calle de Moneda, según un grabado de P. Sellier, publicado por Désiré Charnay en Les anciennes villes du Noveau Monde, voyages d'explorations au Mexique et dans l'Amerique Centrale, I857-1882, París, Hachette $\&$ cie., I885, p. 39.

bién con prendas de lujo- asiéndolo por los cabellos (figs. 3 y 4). Pese a la reiteración de los pares de personajes en las quince escenas, existía una variante cuyo significado captó muy pronto la atención de los entendidos: asociado a la figura de cada guerrero capturado había un glifo toponímico y en su conjunto las escenas correspondían a quince pueblos conquistados por los mexicas.

En cuanto la piedra volvió a la luz, se iniciaron los estudios de los relieves. León y Gama inquirió sobre la técnica de talla; recurrió a las fuentes documentales para encontrar los registros históricos tempranos que hablaran de la fabricación de la pieza y de sus funciones rituales; rechazó que fuese una piedra de sacrificio y pretendió identificar los glifos toponímicos con los pueblos sujetos a los mexicas. A su juicio, éstos eran quince pueblos que debían acudir por turnos a Tenochtitlan para contribuir en las fiestas rituales. ${ }^{\text {IO }}$ 


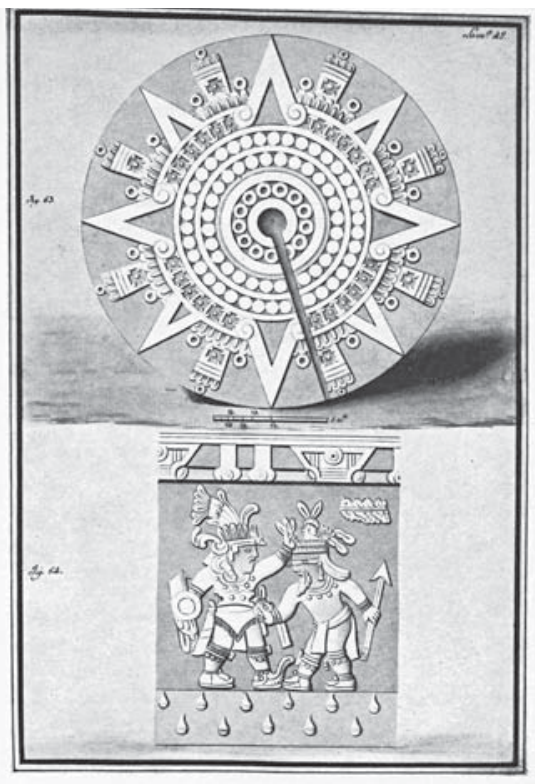

3. La cara superior y un segmento de la cara lateral de la Piedra de Tízoc, según un dibujo del llamado Manuscrito de Sevilla, en Guillermo Dupaix, Expediciones acerca de los antiguos monumentos de la Nueva España, I805-I808, José Alcina Franch (edición, introducción y notas), Madrid, Ediciones José Porrúa Turanzas (Colección Chimalistac), 1969, lám. I29, figs. 63 y 64.

Como ninguno de los historiadores hace mención de las circunstancias que concurrían en esta fiesta [Hueitecuhílhuitl], aunque es facil conocer el número [I5] de pueblos que asistían a ella, por manifestarse en la misma piedra, la interpretación de algunos de sus símbolos es tan difícil, que sólo se puede deducir convinando diversos pasages de la historia; de esta manera con no poco trabajo y estudio hé inferido cuales pudieran ser algunos de los pueblos, cuyos geroglificos no se encuentran en las pinturas que tengo en mi poder. ${ }^{\text {II }}$

Hombres notables continuaron con la investigación de las escenas laterales del monolito. Antonio Peñafiel distingue entre ellos a Guillermo Dupaix, Alexander von Humboldt, José Fernando Ramírez y Jesús Sánchez, quien fuera director

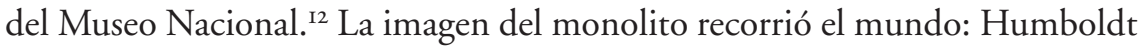
incluyó dos de los pares de vencedor y vencido, y tres de los glifos toponímicos en la lámina 2I de sus Vues des cordillères et monuments des peuples indigènes de

\section{Ibidem, p. 63.}

I2. Antonio Peñafiel, "Destrucción del Templo Mayor de México", en Eduardo Matos Moctezuma (comp.), Trabajos arqueológicos en el centro de la ciudad de México (Antología), México, Instituto Nacional de Antropología e Historia, 1979, p. II2. 


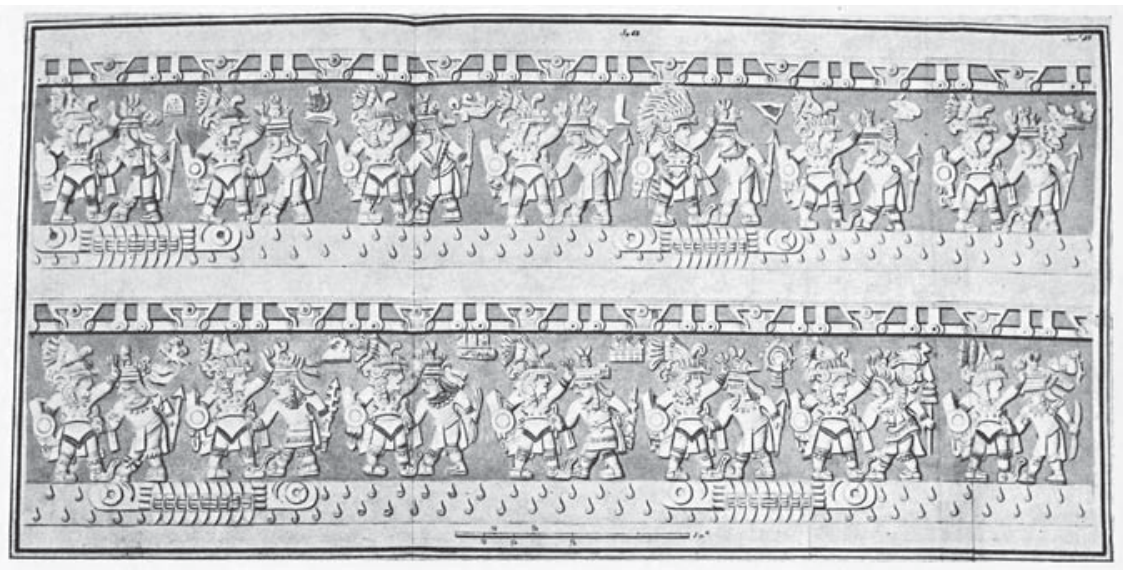

4. La cara lateral de la Piedra de Tízoc, dividida en dos mitades, según un dibujo del llamado Manuscrito de Sevilla, en Guillermo Dupaix, Expediciones acerca de los antiguos monumentos de la Nueva España, I805-I808, José Alcina Franch (edición, introducción y notas), Madrid, Ediciones José Porrúa Turanzas (Colección Chimalistac), I969, lám. I30, fig. 65.

l'Amérique (fig. 5), ${ }^{13}$ y Carlos Nebel dio a conocer tempranamente la pieza, publicando tres muy buenos grabados y explicando los glifos en Viaje pintoresco y arqueológico sobre la parte más interesante de la república mexicana, en los años transcurridos desde I 829 hasta I834 (fig. 6). ${ }^{I 4}$

Desde aquellos tiempos perduran problemas centrales relativos a la función del monolito; a la posibilidad de atribuir las victorias al tlatoani Tízoc, cuyo nombre aparece grabado en la piedra; a la correspondencia entre los quince glifos toponímicos de los cautivos y las listas de las conquistas mexicas — en especial las del Códice mendocino-; al hecho de que los personajes representados sean humanos o tengan el carácter de divinidades patronales, y a que el conjunto de pueblos mencionados integre una lista de conquistas o sea una referencia general o un cosmograma del dominio mexica. ${ }^{\text {I5 }}$ El problema de la naturaleza ritual del

I3. Alexander von Humboldt, Vistas de las cordilleras y monumentos de los pueblos indígenas de América, 2 vols., México, Siglo XXI, 1995.

I4. Carlos Nebel, Viaje pintoresco y arqueológico sobre la parte más interesante de la república mexicana, en los años transcurridos desde I829 hasta I834, Justino Fernández (prólogo), México, Librería de Manuel Porrúa, 1963, pp. XXIII-XXIV.

I5. Richard F. Townsend, State and Cosmos in the Art of Tenochtitlan, Washington, Dumbarton Oaks, I979, p. 47. 


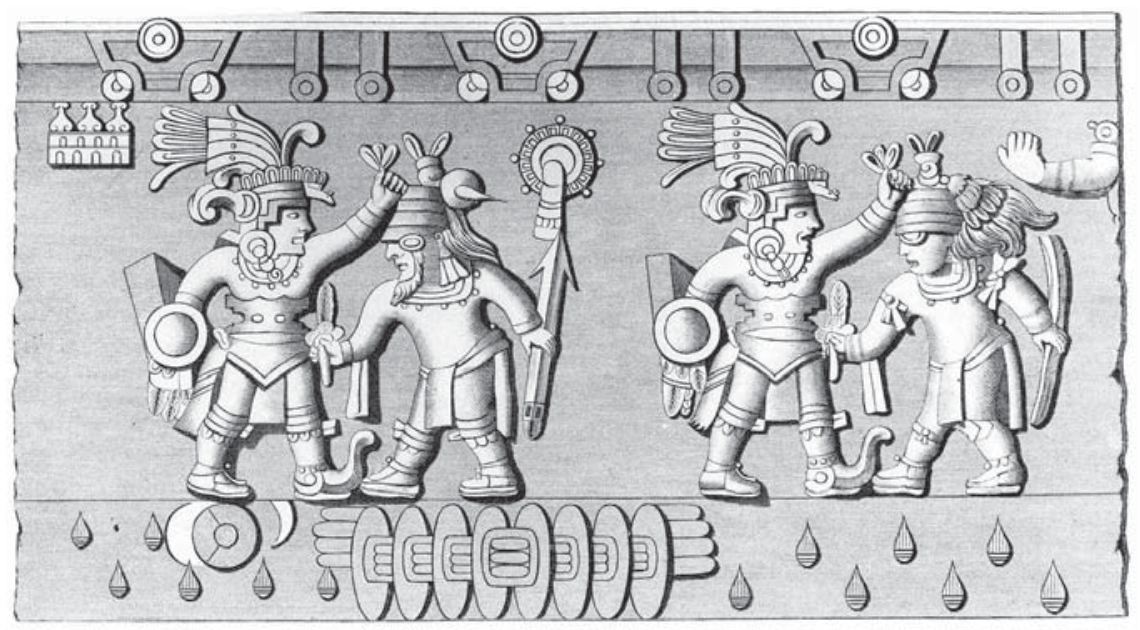

5. Dos pares de vencedor-vencido de la cara lateral de la Piedra de Tízoc, según un grabado copiado de un dibujo de Dupaix y publicado por Alexander von Humboldt en Vues des cordillères et monuments des peuples indigènes de l'Amérique, París, F. Schoell, I8Io, lám. 2I.

monolito fue atacado con gran tino por Manuel Orozco y Berra, según quien la pieza era un cuauhxicalli y no un téchcatlo piedra sacrificial, ${ }^{16}$ opinión ratificada años después por Eduard Seler. ${ }^{17}$ Por otra parte, en la actualidad los glifos de la Piedra de Tízoc son ejemplos privilegiados en la discusión sobre el fonetismo de la escritura mexica anterior a la conquista: ${ }^{18}$ por una parte, no aparecen en ellos elementos fonéticos como pan, tlan, ten y co; por la otra, ha sido puesto en duda el origen prehispánico de documentos que sí muestran dichos elementos fonéticos. ${ }^{19}$

No es mi intención, al menos por ahora, intervenir en la discusión de tan importantes temas. Pretendo, como anteriormente anuncié, resolver una rela-

16. Orozco y Berra, op. cit., pp. 3, 6 y I4.

17. Seler, op. cit., pp. I3I y I9I, n. 54 .

I8. Charles E. Dibble, "Writing in Central Mexico", en R. Wauchope (comp.), en Handbook of Middle American Indians, Archaeology of Northern Mesoamerica, Ia. parte, Austin, University of Texas Press, 1971, vol. ro.

19. Entre los documentos que contienen elementos fonéticos están la Tira de la peregrinación, el Códice borbónico y la Matrícula de tributos. Donald Robertson, Mexican Manuscript Painting of the Early Colonial Period. The Metropolitan Schools, New Haven, Yale University Press, 1959, p. 93, considera que estas obras son coloniales. 

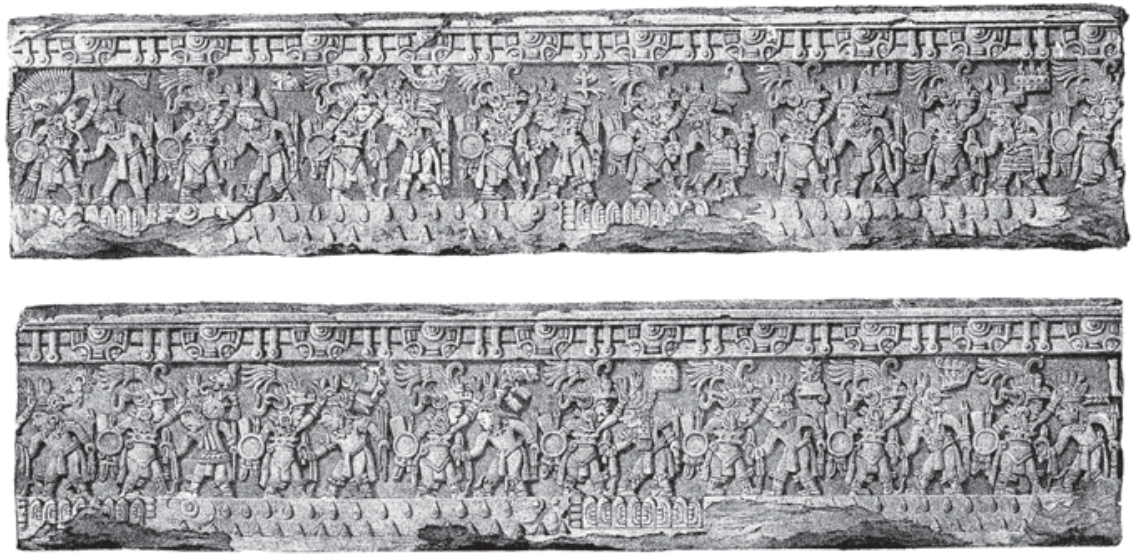

6. La cara lateral de la Piedra de Tízoc, según una litografía de Carlos Nebel, publicada en Viaje pintoresco y arqueológico sobre la parte más interesante de la república mexicana, en los años transcurridos desde I829 hasta I834, Justino Fernández (prólogo), México, Librería de Manuel Porrúa, 1963, lám. 45 .

ción entre la cosmovisión, la mitología y un glifo. La interpretación de la escena en que aparece este glifo ha sido objeto de debate desde finales del siglo XviII hasta nuestros días (fig. 7). Es la parte dañada por el grosero canal que estropeó la escultura; aunque, hay que decirlo, el destrozo no impide distinguir sus elementos principales.

En forma muy sintética puede afirmarse, por lo pronto, que el glifo tiene como figura central un extraño cuadrúpedo. León y Gama dio al glifo el valor de Tozantlalpan, identificando el nombre de un pueblo de Hueipochtlan, provincia conquistada por Motecuhzoma Ilhuicamina. ${ }^{20}$ Orozco y Berra criticó tal atribución, considerando que León y Gama no había tenido más fundamento que la apariencia remota del animal. "La cuestión es de vista”, juzgó Orozco y Berra, quien argumentó en contra de la opinión vertida: "Gama vio la totzan, ${ }^{2 \mathrm{I}}$ tuza, especie de topo, ${ }^{22}$ tuza, sobre el símbolo tlalli, tierra, de donde sacó Totzan-tlal-pan, sobre la tierra de las tuzas, sobre el tuzal ó topera”. ${ }^{23}$ Orozco y

20. León y Gama, op. cit., p. 66.

2I. Tozan, roedor de la familia de los geómidos. Con el nombre se comprenden especies de los géneros Geomys, Thomomys, Pappogeomys y Heterogeomys. Véase Leonardo Manrique y Jimena Manrique, Flora y fauna mexicanas. Panorama actual, México, Everest Mexicana, 1988, p. 72.

22. No hay tal parentesco: la tuza es roedor; el topo es insectívoro.

23. Orozco y Berra, op. cit., p. 34. 


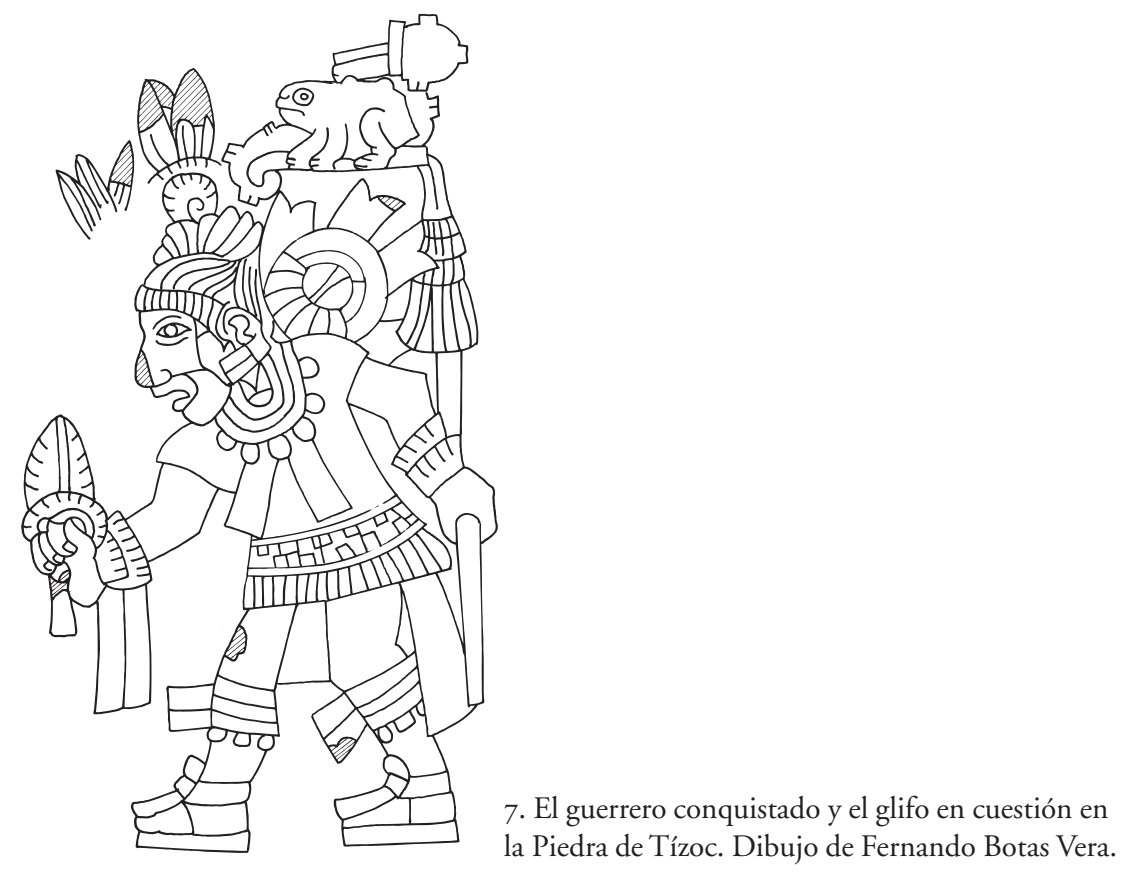

Berra estimó que era otro el animal y corrigió: "Nosotros distinguimos el sapo, tamazollin, sobre el fonético afijo apan, leyendo Tama-zol-apan, sobre el agua de los sapos". ${ }^{24} \mathrm{El}$ historiador dio como base iconográfica de su propuesta el Códice mendocino (fig. 8). ${ }^{25}$ Para justificar el nombre en el contexto histórico, argumentó que, aunque el nombre del pueblo no aparece en las listas de las conquistas mexicas, pertenece al territorio oaxaqueño invadido en $\mathrm{I} 486 .{ }^{26}$

Alfredo Chavero no estuvo de acuerdo con la identificación de Orozco y Berra, aunque la mencionó en su Historia antigua y de la conquista, primer tomo de la monumental obra dirigida por Vicente Riva Palacio, México a través de los siglos. A juicio de Chavero, el glifo pertenece a Xaltocan, ${ }^{27}$ lo que hace indispensable suponer que dio a la figura del animal el valor de "araña de la arena".

24. Idem.

25. Véase Codex Mendoza, ed. facs., Berkeley, University of California Press, 1992, f. 43r, tercera figura de la columna de la izquierda.

26. Orozco y Berra, op. cit., p. 34.

27. Alfredo Chavero, Historia antigua y de la conquista, en Vicente Riva Palacio (comp.), México a través de los siglos, México, Publicaciones Herrerías, vol. I, s.f. p. 682. 
8. Glifo toponímico de Tamazolapan. Dibujo de Fernando Botas Vera basado en el Codex Mendoza, ed. facs., Berkeley, University of California Press, I992, f. 43r.
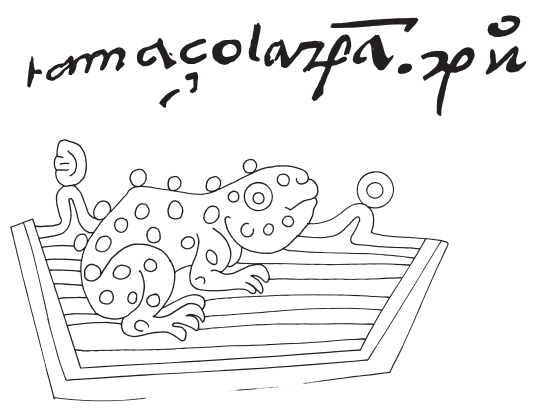

Tiempo después preocupó a Peñafiel la correlación entre los nombres de los pueblos conquistados por Tízoc y los quince glifos toponímicos de la piedra. Observó que, según el Códice mendocino, son sólo catorce los pueblos conquistados por este tlatoani; pero uno es Tamapachco, y éste puede vincularse con el glifo en cuestión. Reconociendo que la figura del glifo corresponde a un sapo, Peñafiel destacó la posibilidad de que el sustantivo náhuatl tuviera un valor fonético, en particular aplicado a un topónimo huasteco. Tam, señaló Peñafiel, es la radical que significa lugar en lengua huasteca; pero los hablantes de náhuatl pueden expresar el sonido huasteco con la figura de un sapo, tamazolin. ${ }^{28}$ Peñafiel criticó las interpretaciones que daban como topónimo Tamazolapan, pues a su parecer no justificaban el elemento apan, que significa agua. Dijo que no se conocía el significado de la figura que está sobre el sapo; pero afirmó que podía ser entendida como "el lugar fue conquistado". En resumen, para Peñafiel, de los quince topónimos del monolito, sólo siete (Matlaltzinco, Tochtla, Ahuilizapán, Tamapachco, Tecaxic, Ehecatepec y Cuetlaxtlán) son conquistas de Tízoc, mientras que los restantes corresponden a victorias de tlatoque anteriores. ${ }^{29}$

A Seler corresponde el mérito de haber precisado la naturaleza de los personajes a partir de una característica física del vencedor (le falta un pie, que es sustituido por un par de columnas de humo) y de los atavíos de todos los componentes de los pares. En el vencedor encontró atributos de Tezcatlipoca ${ }^{30} \mathrm{y}$

28. Ángela Ochoa (comunicación personal) corrobora que Tamapach’ significa en lengua teenek "lugar de palmas" (Sabal mexicana), y agrega que la planta en cuestión es una palma de tronco corto, con hojas en forma de abanico. Asimismo, supone la lingüista que la terminación - co puede ser un agregado náhuatl.

29. Peñafiel, op. cit., pp. II3-II5.

30. Entre ellos precisamente el pie faltante y el humo que sale del tobillo mutilado. Alexander 

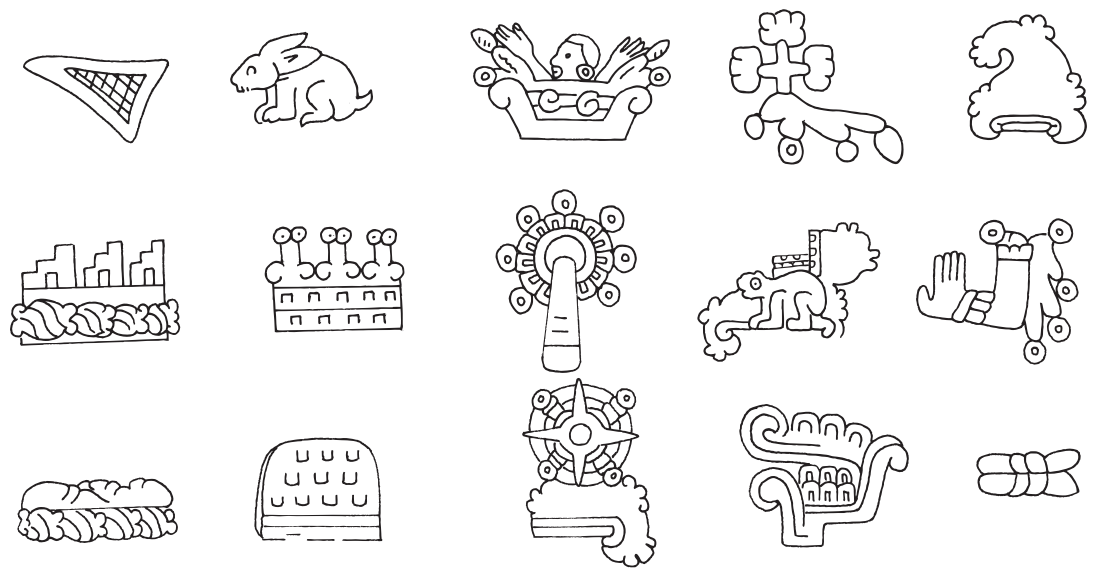

9. Identificación de Eduard Seler de los quince glifos toponímicos de la Piedra de Tízoc.

De izquierda a derecha, en primera fila: Matlatzinco, Tochpan (?), Ahuilizapan, Huexotla

(?) y Colhuacan; en la segunda fila: Tetenanco, Xochimilco, Chalco (?), Tamazollan o

Tamazolapan y Acolhuacan; en la tercera fila: Tepanohuayan, Tlatelolco, Teotitlan, Poctlan (?) y Cuetlaxtlan. Dibujos de Fernando Botas Vera basado en Eduard Seler.

de Xiuhtecuhtli, mientras que la ropa y los ornamentos de los vencidos pueden identificarlos como patronos de las regiones conquistadas. ${ }^{31}$ Seler estudió cada uno de los quince glifos toponímicos (fig. 9) ${ }^{32} \mathrm{y}$, al interpretar el glifo que se estudia en este trabajo, coincidió con Orozco y Berra al decir que corresponde a Tamazolapan, aunque señaló como otra opción Tamazollan, ambas poblaciones pertenecientes a la Mixteca Alta, región atacada por los mexicas durante el régimen de Motecuhzoma Ilhuicamina. Según Seler, el cautivo tiene arma —la lanza larga - y prendas muy diferentes al resto de los representados en la piedra, y parecidas, por el contrario, a las que se muestran en los códices mixtecos. El guerrero lleva en la nuca un gran disco del que penden correas cortadas en figura de cola de golondrina, distintivo semejante al anáhuatl del dios Tezcatlipoca y al anillo de tocado de las figuras de Tepeyollotli. ${ }^{33}$ Hay, además, una atinada

von Humboldt, en Vistas de las cordilleras..., op. cit., vol. I, p. I37, interpreta las volutas del pie de Tezcatlipoca como "una especie de pico que parece destinado a su defensa".

3I. Seler, op. cit., pp. I32-I33.

32. Ibidem, pp. 133-136 y fig. I2.

33. Ibidem, pp. I34-136. 
Io. Glifo toponímico de Azcapotzalco, formado por una extraña hormiga bípeda. Dibujo de

Fernando Botas Vera.

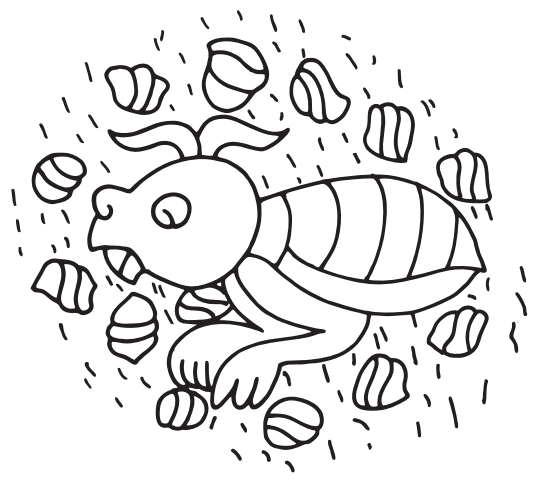

observación en la descripción de Seler: dice que en el glifo "aparece suficientemente claro un sapo (tamazolin) frente a una montaña 'decapitada'." $34 \mathrm{Y}$ este aserto, olvidado por los investigadores, es crucial para nuestro estudio, como podremos ver más adelante.

Marshall H. Saville dedicó una de sus obras al estudio del tlatoani Tízoc. $\mathrm{Al}$ referirse al monolito descrito, reconoció que eran muchas las opiniones de los estudiosos acerca del glifo en cuestión, y resolvió suscribir la de Peñafiel por considerarlo un investigador distinguido; el glifo es Tamapachco, nombre de una población huasteca. ${ }^{35}$

En muchas pictografías prehispánicas y coloniales existe una increíble libertad al representar animales. Las pinturas pueden distar considerablemente de las características anatómicas de las especies a que se refieren. El Códice mendocino es una de las fuentes en que aparecen con frecuencia formas apartadas de la precisión zoológica. Así, en este documento, se representa una hormiga con sólo dos patas en forma de brazos y con incisivos de roedor (fig. Io)..$^{36}$ James Cooper Clark, al editar dicho códice en I938, se basó en estas libertades estilísticas para justificar una interpretación histórica que consideró más aceptable: el investigador identificó la novena escena de la Piedra de Tízoc (la del glifo en cuestión) como la conquista de Azcapotzalco, ${ }^{37}$ ciudad cuyo nombre significa "en el hormiguero".

34. Ibidem, pp. 134 .

35. Marshall H. Saville, "Tízoc: Great Lord of the Aztecs I48I-I486", Contributions from the Museum of the American Indian Heye Foundation, vol. VII, núm. 4, I929, p. 48.

36. Codex Mendoza, op. cit., f. 5v, figura superior izquierda.

37. James Cooper Clark, Codex Mendoza. The Mexican Manuscript Known as the Collection of Mendoza and Preserved in the Bodleian Library Oxford, Londres, Waterlow \& Sons, 1938, vol. I, p. 36, n. 7 . 

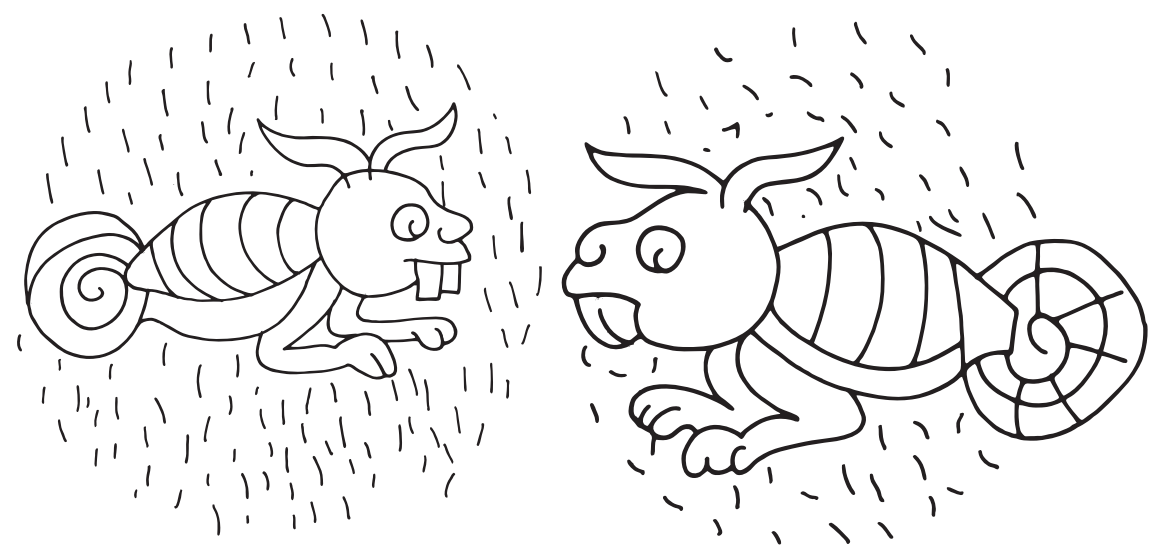

II. Dos glifos toponímicos de Xaltocan, con arañas bípedas. Dibujos de Fernando Botas Vera.

Charles E. Dibble devolvió al animal la calidad de sapo y opinó que el glifo corresponde al topónimo Tamazollan..$^{38}$ Pero, en 1976, Charles E. Wicke disminuyó de nuevo el tamaño para ver en él una araña, con lo cual retornó a la distante opinión de Chavero, sin mencionarlo. Según Wicke, la escena representa la importante conquista de Xaltocan. Como Peñafiel, este autor considera que los glifos toponímicos de la Piedra de Tízoc se refieren tanto a las conquistas de este tlatoani como a las de sus antecesores, y en la lista ampliada destaca la derrota que los mexicas infligieron a Xaltocan, cuyo topónimo se traduce como "lugar de la araña de la arena". Nuevamente la laxitud de representación del Códice mendocino justifica la propuesta. En la pictografía aparecen con el significado de arañas dos dibujos de bichos muy semejantes a la hormiga de Azcapotzalco, incluso con el mismo tipo de antenas, los incisivos de roedor y sólo dos patas frontales en forma de brazos (fig. II). ${ }^{39}$ Wicke notó que en los arácnidos del Códice mendocino se resalta un importante elemento anatómico: las hileras, aparato que permite a las arañas formar su tela. Este investigador afirmó que las hileras están representadas por una pequeña mancha roja al final del abdomen. Su observación parece justa, pues podemos encontrar igual marca en un dibujo colonial de muy diferente estilo: la araña del folio 93r del libro XI del Códice florentino. Pero Wicke fue más allá, al afirmar que las hileras también

38. Dibble, "Writing in...", op. cit., pp. 327-328.

39. Codex Mendoza, op. cit., ff. $3 \mathrm{v}$ y I7v. 
están representadas en la parte posterior del cuerpo del animal en el glifo tallado en la Piedra de Tízoc. ${ }^{\circ}$ Este argumento no es válido: lo que se encuentra detrás del animal del monolito no es parte de su cuerpo, sino el borde lateral de un monte roto. En este borde hay un par de salientes, elementos comunes en las representaciones escultóricas y pictográficas de los cerros, y que aluden a la naturaleza pétrea. ${ }^{4 \mathrm{I}}$ Cabe advertir que la identificación de Wicke ha sido seguida por otros autores importantes, entre quienes se encuentra Esther Pasztory. ${ }^{42}$

Hasta aquí se habían establecido los puntos más interesantes del debate, cuando el $\mathrm{I}^{\circ}$ de julio de 1988 un nuevo descubrimiento enriqueció notablemente la información. El hallazgo ocurrió a poca distancia del sitio de aparición de la Piedra de Tízoc. La excavación se hizo en el Palacio del Arzobispado, edificio colonial sito en la calle de Moneda número 4. Cuando el equipo del Departamento de Salvamento Arqueológico dirigido por Pedro Francisco Sánchez Nava removió una fuente en el patio norte del edificio, salió a la luz un monolito de prodigiosa semejanza a la Piedra de Tízoc. ${ }^{43}$ Esta escultura ha recibido diferentes nombres: Piedra del Ex-Arzobispado, ${ }^{44}$ Piedra Sánchez Nava, Cuauhxicalli de Motecuhzoma Ilhuicamina y Piedra de Axayácatl. Los dos últimos nombres parten del supuesto de que las victorias representadas eran las celebradas en la época de arranque de la expansión mexica. La Piedra del Ex-Arzobispado se talló en una roca más suave que el material de la Piedra de Tízoc, sus escenas están incluidas en cartuchos que las separan nítidamente (fig. I2), la labra es más rígida, se representan cuatro escenas menos que en la Piedra de Tízoc y la talla se adapta a las irregularidades de la piedra. Estas características han llevado a concluir a los especialistas que la Piedra del ExArzobispado es más antigua que la de Tízoc.

Las escenas de vencedores y cautivos de la Piedra del Ex-Arzobispado se encuentran en la misma secuencia de las de su monolito hermano. Las cuatro faltantes son las que en la Piedra de Tízoc aparecen entre la conquista de

40. Charles E. Wicke, "Once More around the Tizoc Stone. A Reconsideration”, Actas del XLI Congreso Internacional de Americanistas, México, 2-7 de septiembre de 1974, 1976, p. 215.

4I. La misma opinión se encuentra en Graulich, "Notas sobre el llamado Cuauhxicalli-Temalácatl de Motecuhzoma Ilhuicamina”, Cuicuilco, nueva época, vol. 5, n. I4, septiembre-diciembre de 1998 , p. 242.

42. Esther Pasztory, Aztec Art, Nueva York, Harry N. Abrams, 1983, p. I49, lám. 93.

43. Tiene un diámetro de $2.14 \mathrm{~m}$ y una altura que varía entre $68 \mathrm{~cm}$ y $76 \mathrm{~cm}$.

44. Pese a que las actuales normas gramaticales suprimen el guion tras la partícula ex, aquí se respeta la denominación que ha recibido el monolito. 

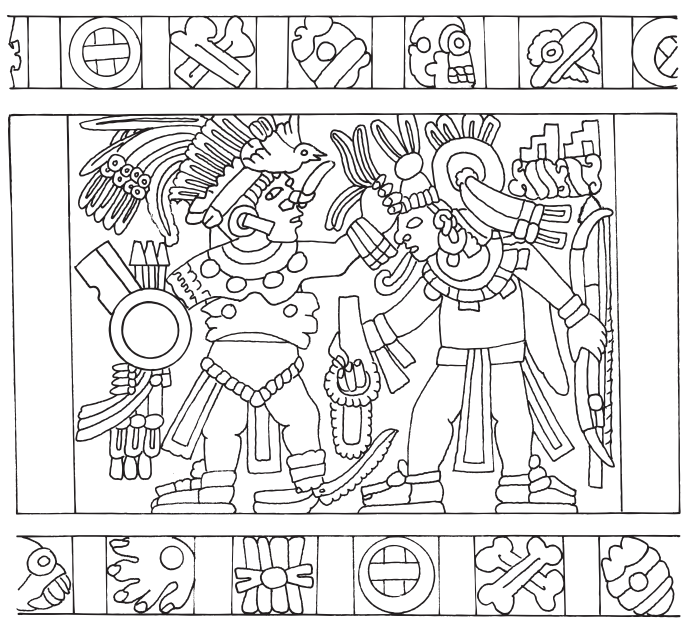

I2. Uno de los cartuchos de la Piedra del Ex-Arzobispado. Dibujo de Fernando Botas Vera.

Cuetlaxtlan y la de Culhuacan. Por tanto, existe en ella la escena en que se encuentra el glifo en cuestión, y el glifo es una variante iconográfica de enorme interés para el tema que ahora se trata (figs. 7 y I3).

¿Qué interpretaron los especialistas a partir del segundo hallazgo? Simplemente, el problema específico continuó su trayectoria, abarcando ambos monumentos; subsistió la diversidad de opiniones, y en algunos casos apareció la indecisión cuando se tuvo que hacer el listado de las conquistas. En un trabajo muy próximo al descubrimiento, en 1989, Guillermo Pérez-Castro, Sánchez Nava, Stefan, Padilla y Yedra, y Gudiño Garfias aceptaron la tesis de que el glifo corresponde a Xaltocan; ${ }^{45}$ pero en el mismo año los citados Padilla y Sánchez Nava, ahora con Felipe Solís Olguín, se inclinaron por identificarlo con Tamazolapan. ${ }^{46}$ Por su parte, Solís sostuvo su opinión anterior en un artículo firmado individualmente; ${ }^{47}$ pero en otros trabajos, al referirse a las escenas paralelas de ambos monolitos, ha dicho que el glifo pudiera remitir a Tamazulapan o a Xaltocan. ${ }^{8}$

45. Guillermo Pérez-Castro Lira et al., "El Cuauhxicalli de Moctezuma I", Arqueología, México, vol. 5 , 1989, p. 143 .

46. Padilla et al., "The Cuauhxicalli of Motecuhzoma Ilhuicamina”, Mexicon, vol. XI, núm. 2, marzo de 1989 , p. 25.

47. Felipe Solís, "Un nuevo cuauhxicalli descubierto en la ciudad de México", Boletín Informativo del Museo Nacional de Antropología, año II, vol. 4, julio de 1989, pp. IO-II.

48. Felipe Solís, Gloria y fama mexica, México, Smurfit Cartón y Papel de México, 1991, pp. I57I58; "El temalácatl-cuauhxicalli de Moctezuma Ilhuicamina”, en José Alcina Franch et al. (comps.), 
I3. El guerrero conquistado y el glifo en cuestión en la Piedra del Ex-Arzobispado. Dibujo de Fernando Botas Vera.

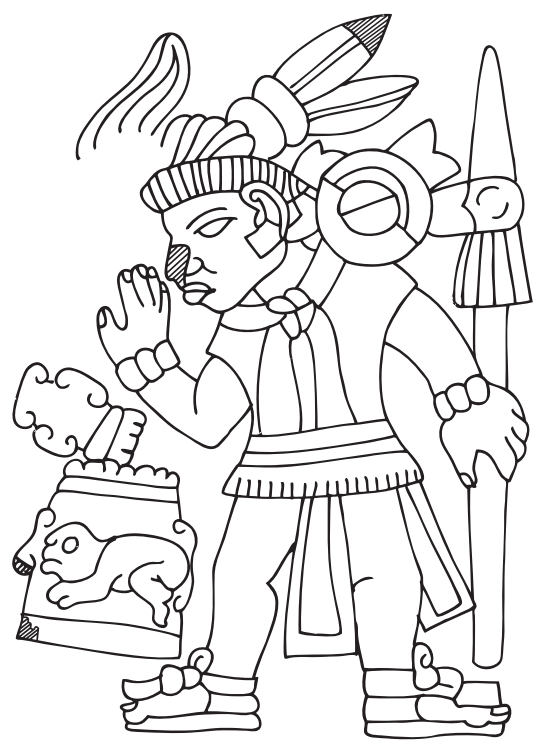

Con el estudio de la Piedra del Ex-Arzobispado vuelve a ponerse en la mesa de discusión la antigua propuesta de Clark, en el sentido de que el glifo se refiere a Azcapotzalco, aunque no se hace referencia al editor del Códice mendocino. Uno de quienes externan esta opinión es Michel Graulich, pues identifica el animal con una hormiga y da el sentido de hormiguero al monte que forma parte del glifo. ${ }^{49}$ Graulich sostiene que la representación de Azcapotzalco es históricamente lógica, ya que la conquista de esta ciudad — como la conquista de Colhuacan - significó una refundación del Estado mexica, agregando que la secuencia histórica de las conquistas concuerda con la de las figuras del monumento..$^{50}$ Igual identificación y parecidos argumentos propondrá Emily Umberger, indicando que el elemento que se encuentra tras el animal es "un

Azteca-mexica, Madrid, Instituto Nacional de Antropología e Historia/ Sociedad Estatal Quinto Centenario / Lunwerg, 1992, p. 229; Felipe Solís y Roberto Velasco Alonso, "Testimonios arqueológicos sobre el culto solar en México prehispánico”, en Eduardo Matos Moctezuma y Felipe Solís (comps.), El Calendario Azteca y otros monumentos solares, México, Consejo para la Cultura y las Artes-Instituto Nacional de Antropología e Historia / Grupo Azabache, 2004, pp. III y I2O.

49. Michel Graulich, "On the So-called 'Cuauhxicalli of Motecuhzoma Ilhuicamina', the Sánchez Nava Monolith”, Mexicon, vol. xiv, núm. I, enero de I992, p. 6; "Notas sobre...”, op. cit., p. 242.

5o. Graulich, "Notas sobre...", op. cit., p. 242. 


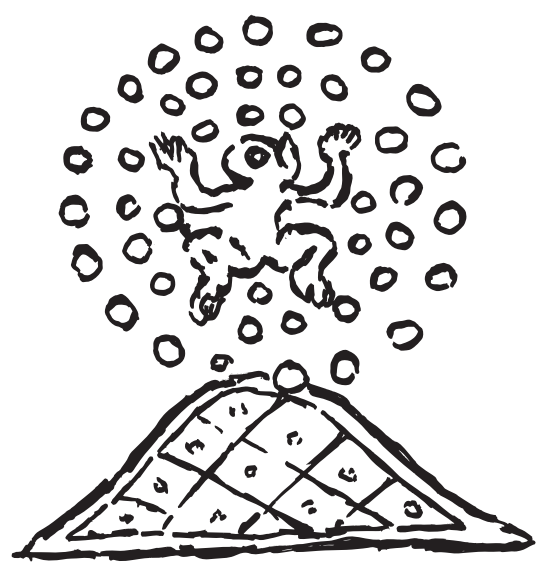

\begin{abstract}
I4. Glifo toponímico de Azcapotzalco donde la araña es cuadrúpeda, en el Códice Xólotl, 2a. ed., Charles E. Dibble (edición y estudio), México, Universidad Nacional Autónoma de México-Instituto de Investigaciones Históricas, I980, v. II, 2, plancha 6, E3.
\end{abstract}

monte con su tapa volcada hacia uno de los lados". Agrega la autora que otra figura anómala de hormiga, con cuatro patas, corresponde asimismo al glifo de Azcapotzalco y puede verse en el Códice Xólotl (fig. I4). .r $^{\text {I }}$

Por último, debo mencionar una tesis profesional reciente, cuya autora aborda conjuntamente el problema de los glifos toponímicos de la Piedra del ExArzobispado y de la Piedra de Tízoc. Al estudiar ambas versiones del glifo, María Teresa Neaves Lezama toma en cuenta que la parte superior del monte se encuentra rota y desprendida, por lo que, aun cuando no se decide por la identificación del animal representado, da como elemento común de las versiones tentativas la referencia a un cerro desgajado. ${ }^{22}$ La propuesta de Neaves Lezama hace recordar el enunciado ya muy distante — aunque puntual y preciso— de Seler, quien calificó la parte de fondo del glifo como "una montaña 'decapitada".

\title{
Tras la explicación del glifo
}

Puntualicemos el problema en lo que se refiere al ícono. En las dos versiones talladas en piedra, el glifo está claramente compuesto por dos elementos: un animal en el primer plano y un monte en el segundo (fig. I5). El animal es tetrápo-

5I. Emily Umberger, "New Blood from an Old Stone", Estudios de Cultura Náhuatl, vol. 28, 1998, p. 25I. Véase Códice Xólotl, 2a. ed., Charles E. Dibble (edición y estudio), México, Universidad Nacional Autónoma de México-Instituto de Investigaciones Históricas, 1980, vol. II, 2, plancha 6, E3.

52. María Teresa Neaves Lezama, "Los glifos toponímicos en las esculturas conocidas como 'Pie- 


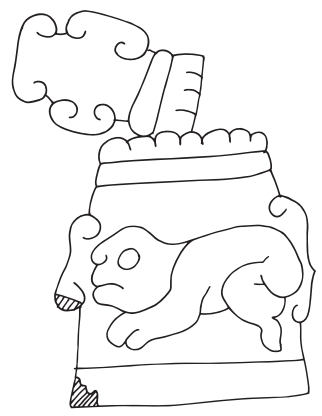

a)

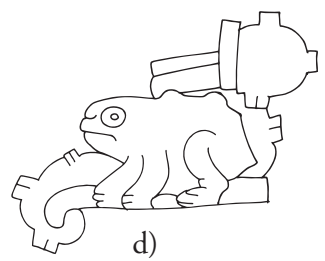

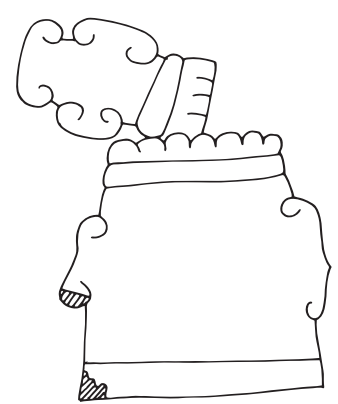

b)

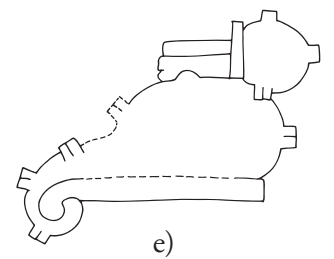

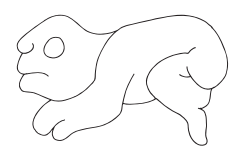

c)

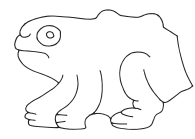

f)

I5. El glifo en cuestión. En la Piedra del Ex-Arzobispado: a) glifo completo, b) monte, c) anuro. En la Piedra de Tízoc: d) glifo completo, e) monte, f) anuro. Dibujos de Fernando Botas Vera.

do; su cuerpo es corto y robusto, aun rechoncho en la Piedra de Tízoc; no hay segmentación entre tórax y abdomen, y ni siquiera entre tórax y cabeza en este último monolito; la región sacra se deprime bruscamente; sus extremidades están bien desarrolladas, sobre todo las posteriores, que se doblan; su cuerpo está desnudo, sin indicación de pelo ni escamas; su boca es amplia y sus ojos son globosos; no hay pabellones auriculares ni indicación alguna de antenas o cuernos; carece de apéndice caudal. En resumen, las imágenes son batracomorfas — como apreciara Orozco y Berra- y corresponden zoológicamente, sin lugar a dudas, a individuos del orden de los anuros. Esto se ve hasta en la mencionada inclinación brusca de la columna en la región sacra, presente en los anuros por la fusión de las últimas vértebras, que al unirse forman el hueso coccígeo o uróstilo.

¿Corresponde esta representación a la iconografía indígena de los anuros? Podemos observar el parecido tanto en dibujos de fuerte estilo prehispánico

dra del Ex-Arzobispado’ y 'Piedra Tízoc”, tesis de licenciatura en Historia, México, Universidad Nacional Autónoma de México-Facultad de Filosofía y Letras, 2005, pp. 58 y 129. 

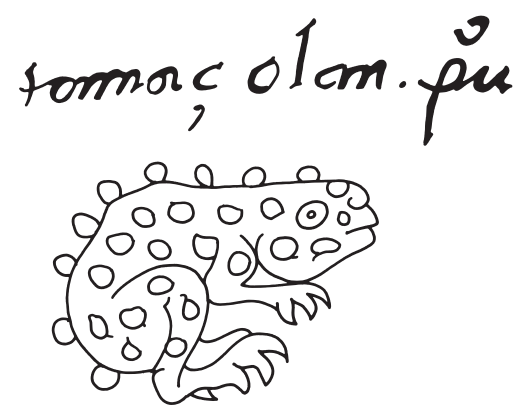

I6. Glifo toponímico de Tamazollan.

Dibujo de Fernando Botas Vera.

como en los que ya tienen influencia europea. Ejemplos de los primeros son los sapos de los glifos de Tamazollan y Tamazolapan del Códice mendocino y de la Matrícula de tributos (figs. 9, I6 y 17); 53 de los segundos son las ranas y los sapos del Códice florentino (figs. I8 y 19). ${ }^{54}$

Ahora bien, ¿los anuros de las piedras del Ex-Arzobispado y de Tízoc son ranas o son sapos? Si comparamos los sapos y las ranas de las pictografías antes mencionadas, veremos que una de las propiedades distintivas en las representaciones es que los sapos de los dos documentos están dibujados con su característica piel verrugosa y rica en glándulas, mientras que las ranas sólo muestran las manchas de su piel. En la Piedra del Ex-Arzobispado el animal carece de las glándulas, mientras que en el relieve de la Piedra de Tízoc aparecen en el dorso del animal, claramente perfiladas, dos protuberancias en forma de hemiciclos. Se trata, al parecer, de individuos de dos familias diferentes del orden de los anuros, perteneciente el primero a una especie de ranas y el segundo a una de sapos.

Al continuar con el análisis del segundo plano, puede verse un monte que está tronchado, por lo que su cúspide se inclina. $\mathrm{Al}$ parecer por razones de simple composición, la cúspide del de la Piedra del Ex-Arzobispado cae hacia la izquierda y la de la Piedra de Tízoc, hacia la derecha. En el primero de los monolitos el monte descansa en su característica base en forma de barra horizontal; sus pendientes son pronunciadas, lo que le da aspecto de cono truncado; su naturaleza pétrea se indica con los grandes salientes laterales en forma

53. Ambos glifos en la lámina 43r del Codex Mendoza, op. cit., correspondiente a los pueblos de la provincia oaxaqueña de Coaixtlahuacan.

54. En el Códice florentino, op. cit., aparecen cuatro figuras de ranas en el lib. XI, cap. III, pár. $5^{\circ}$, f. $67 \mathrm{v}$, y de sapos en el mismo lib. XI, cap. IV, pár. $4^{\circ}$, una en el f. $76 \mathrm{r}$ y otra en el $76 \mathrm{v}$. 
17. Glifo toponímico de Tamazollan en la Matrícula de tributos, María Teresa Sepúlveda (interpretación y análisis), Miguel León-Portilla (introd.), historia de la Matrícula de Víctor M. Castillo Farreras, Arqueología Mexicana (edición especial, I4), 2003, lám. 23.

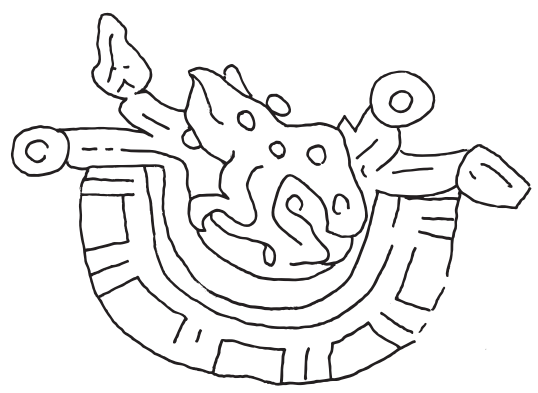

de roleos, característicos de la iconografía mesoamericana, que aquí aparecen tanto en sus laderas como en la cúspide desprendida; tanto en el cuerpo bajo de la montaña como en su parte superior desprendida aparece representado el corte en cercén con las también convencionales franjas ribeteadas con curvas, forma que señala los bordes de la mutilación y que puede observarse, para señalar un solo ejemplo, en los cortes del cuerpo desmembrado de la famosa escultura discoidal de Coyolxauhqui; el cuerpo de la cúspide, desprendido, está exageradamente alargado, con lo cual los tres grandes salientes que indican su constitución pétrea le hacen adquirir la figura cruciforme del árbol, ambigüedad simbólica que puede considerarse intencional.

El monte de la Piedra de Tízoc también descansa en la barra horizontal, pero posee una peculiaridad estilística que no es común: no hay en él una simetría bilateral, sino que una de sus laderas es sumamente empinada, mientras que la otra desciende en suave pendiente. Lo mismo podemos observar en otros montes de la misma serie de glifos toponímicos: en la Piedra del Ex-Arzobispado, el glifo de Tlatelolco, y en ambos monolitos el glifo generalmente atribuido a Tonatiuhco (atribuido también a Teotitlan, Tonaltépec y Tonallimoquetzalla), compuesto por un monte del que sale el Sol (fig. 20). En los dos glifos de la Piedra del Ex-Arzobispado la falda de la ladera de pendiente suave cae hasta flanquear la barra horizontal que forma la base del monte; en los dos de la Piedra de Tízoc, dicha banda forma el roleo que envuelve el extremo de la banda, en una composición que es muy común en la iconografía mesoamericana. El monte del anuro de la Piedra de Tízoc tiene en las laderas y en la cúspide pares de salientes casi rectangulares que sustituyen los roleos que indican la constitución pétrea. De la cúspide desprendida surgen dos barras paralelas, diferenciadas en sus extremos distales, que se interpretan como corrientes que brotan de los cuerpos tronchados, motivo también frecuente en la iconografía mesoamericana. 


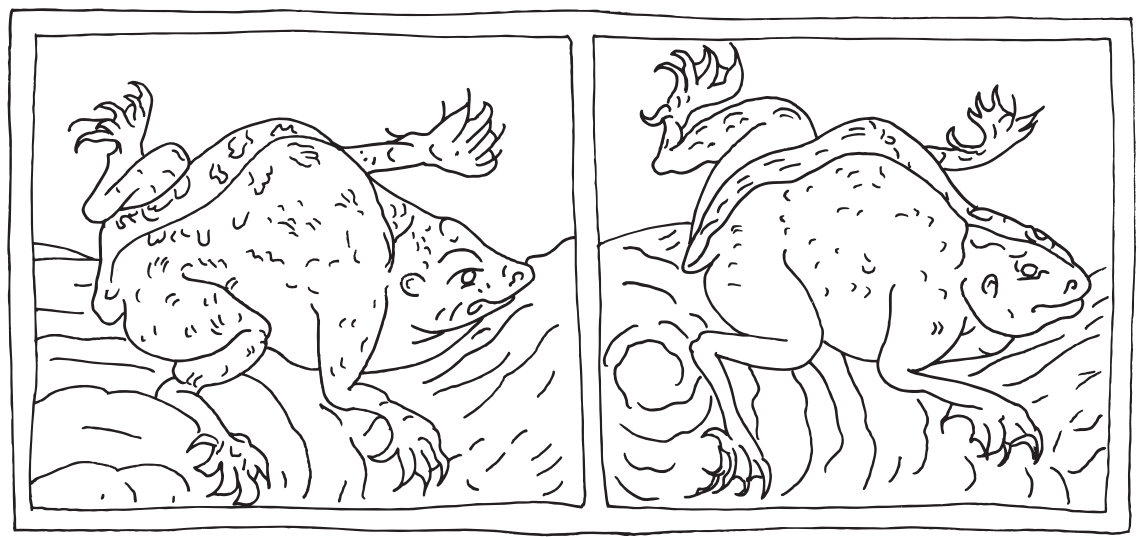

I8. Dos de las cuatro ranas que aparecen en Bernardino de Sahagún. Dibujo de Fernando Botas Vera basado en Bernardino de Sahagún, Códice florentino. Manuscrito 218-20 de la Colección Palatina de la Biblioteca Medicea Laurenziana, ed. facs., 3 vols., México, Secretaría de Gobernación-Archivo General de la Nación, 1979, lib. XI, f. 67v.

La suma de los dos elementos en ambas versiones de este glifo lo hacen muy diferente a los demás glifos de los monolitos estudiados: no parece corresponder al enunciado simple que forma un topónimo. Se percibe en él, al menos, el sintagma "lugar del anuro del monte desgajado", tan complejo que difícilmente pudiera corresponder a un locativo. Serían aceptables, en cambio, "lugar de la rana", "lugar del sapo", "lugar del monte roto", si bien quedaría atrás un significado más profundo, un relato que excede el topónimo: un mito, una leyenda, una imagen cósmica...

¿Cuál es el simbolismo de los anuros en la cosmovisión mesoamericana? Ranas y sapos, desde la antigüedad hasta el presente, son los emisarios de la lluvia, pues su canto anuncia las precipitaciones. Una de las antiguas imágenes pictóricas más claras y conocidas pertenece al Códice Laud, y muestra cuando el animal vierte un cántaro de agua frente al dios de la lluvia (fig. 2I). 55 En cuanto a las concepciones de nuestros días, entre los tzeltales se afirma que el sapo es la esposa del Rayo; ${ }^{56}$ es bien conocida la ceremonia de los mayas yucatecos

55. Códice Laud, ed. facs., México / Graz, Fondo de Cultura Económica/Akademische Druck- u. Verlangsanstalt, 1994, lám. 23.

56. M. Esther Hermitte, Poder sobrenaturaly control social, México, Instituto Indigenista Interamericano, 1970, pp. 30 y 39. 
19. Sapo. Dibujo de Fernando Botas Vera basado en Bernardino de Sahagún, Códice florentino, Manuscrito 218-20 de la Colección Palatina de la Biblioteca Medicea Laurenziana, ed. facs., 3 vols., México, Secretaría de Gobernación-Archivo General de la Nación, 1979, lib. XI, fol. $76 \mathrm{v}$.

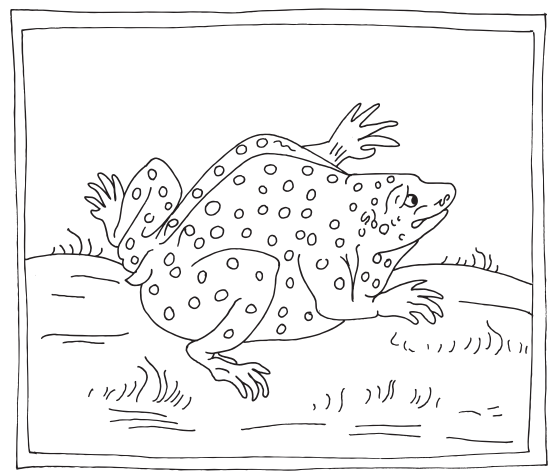

denominada ch'achac, en la que cuatro niños croan para atraer las lluvias; 57 los zapotecos creen que algunas ranas, las peeche xini Cociyo (literalmente "los hijos del Rayo"), son generadas por las lluvias. ${ }^{58}$ Muchos otros pueblos aseguran en nuestros días la existencia de esta estrecha relación..$^{99}$

¿Desde cuándo existen testimonios de estas creencias en Mesoamérica? Manzanilla afirma que es posible identificar arqueológicamente, a partir de restos olmecas, el complejo sapos-ranas vinculado con la representación del agua y con depósitos acuáticos. ${ }^{60} \mathrm{Da}$ abundantes ejemplos de sitios en que las representaciones de anuros están vinculadas al agua, entre ellos Teopantecuanitlan en el Formativo medio; Xochitécatl y Totimehuacan en el Formativo tardío; el bello mural teotihuacano de Tepantitla en el Clásico, y Tezcutzingo en el Posclásico. Pueden agregarse otras muchas obras escultóricas, entre ellas la rana de Teopanzolco y las muy bellas ranitas del Templo Mayor de MexicoTenochtitlan, al pie de la escalinata de Tláloc.

57. J. Eric S. Thompson, Historia y religión de los mayas, México, Siglo XXI, 1975, pp. 2I0-2II, 307 y 315 .

58. Joyce Marcus y Kent V. Flannery, "La clasificación de animales y plantas entre los zapotecos del siglo Xvi. Un estudio preliminar", Cuadernos del Sur, año 7, núm. I6, marzo de 200I, p. I2.

59. Véanse los ejemplos entre mayas peninsulares: Alfonso Villa Rojas, Los elegidos de Dios. Etnografía de los mayas de Quintana Roo, México, Instituto Nacional Indigenista, 1978, p. 430, y entre popolocas y nahuas: Guido Münch Galindo, Etnología del Istmo veracruzano, México, Universidad Nacional Autónoma de México-Instituto de Investigaciones Antropológicas, 1983, p. I70.

6o. Linda Manzanilla, "The Construction of the Underworld in Central Mexico", en Davíd Carrasco et al., (comps.), Mesoamerica's Classic Heritage, Boulder, University Press of Colorado, 2000, pp. 88-IO4. 
II 8 ALFREDO LÓPEZ AUSTIN
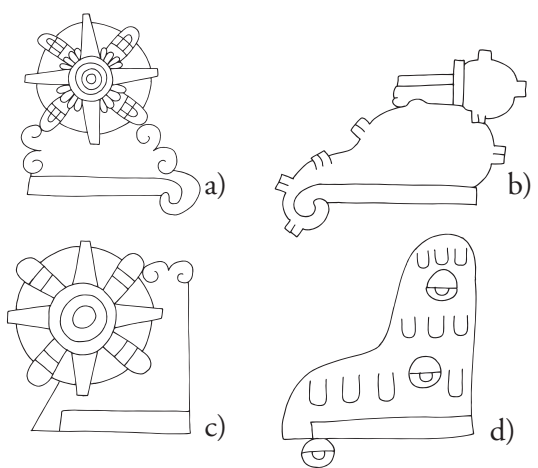

20. Glifos asimétricos de monte en la Piedra de Tízoc: a) Tonatiuhco, b) glifo en cuestión; en la Piedra del Ex-Arzobispado: c) Tonatiuhco, d) Tlatelolco. Dibujos de Fernando Botas Vera.

En cuanto a la figura del monte roto, corresponde, precisamente, a una de las más importantes funciones cosmológicas del Eje Cósmico. Como anteriormente se indicó, existe un segmento del Eje Cósmico que corresponde a la gran bodega en la que se guardan los bienes que han de surgir a la superficie de la tierra, lo que conceptual e iconográficamente tiene como imagen el Monte Sagrado. Uno de los bienes más preciados es el agua, por lo cual el Monte Sagrado es concebido como una enorme olla, en ocasiones como un recipiente-efigie del dios Tláloc. En la actualidad puede oírse que los montes son llamados acuezcómatl, "trojes de agua".

La figura del gran promontorio cósmico se proyecta en la topografía del ecúmeno, por lo cual el monte más alto de las cercanías de un asentamiento humano es considerado su monte sagrado, y a su vez éste se proyecta en montes menores vecinos o, en el pasado, en templos piramidales. Con las proyecciones, el gran suceso mítico de la apertura liberadora de las aguas se convierte en milagro particularizado, y el relato se adopta como parte de la historia prodigiosa de varios asentamientos humanos. Pasemos, pues, a los relatos del gran prodigio.

\section{Cuando se desgajó el monte}

La imagen de un gran promontorio que se rompe y un anuro que irrumpe en la historia del desgajamiento nos lleva a los tiempos míticos según la tradición de los cholultecas. El relato del milagro fue recogido por Motolinía en los primeros tiempos coloniales:

Los de Chololla comenzaron uno [un templo] extremadísimo de grande, que sólo la cepa del teucal que agora aparece terná de esquina a esquina un tiro de ballesta, 
2I. Rana que vierte un cántaro de agua.

Dibujo de Fernando Botas Vera.

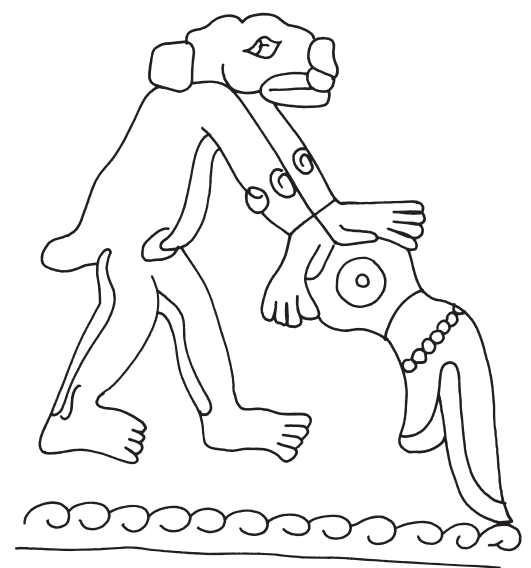

desde esquina a esquina, y desde el pie a lo alto, ha de ser de buena ballesta la que allá eche una vira, y aun los indios naturales chololtecas, muy mucho más señalan que tenía de cepa, y que ésta era más alto mucho de lo que agora está. Éstos quisieron hacer otra locura semejante a los edificadores de la torre de Babilonia, ${ }^{61} \mathrm{y}$ encomenzaron aquel teucal para lo levantar más alto que la más alta sierra de esta tierra; y no muy lejos, sino sólo a siete o a ocho leguas tienen la más alta sierra que creo hay en la Nueva España, que son el vulcán y la sierra blanca, que siempre tiene nieve, que está entre Huexucinco y México, y la sierra de Tlaxcalla, que es asaz de alta; y como éstos quisiesen salir con su locura e edificasen su sierra, confundióles Dios como a los que edificaban la torre de Babel; no multiplicando las lenguas, mas con una tormenta de agua y nube de tempestad, de donde cayó una gran piedra en figura de sapo, y desde allí cesaron. Es tan de ver este edificio, que si no pareciese la obra ser de piedra y adobe, ninguno creería sino que era cerrejón o sierra. Andan en él como conejos y hartas víboras; en lo alto de este edificio estaba un teucalviejo y pequeño, y desbaratáronle los frailes $[\ldots]^{62}$

El teucal a que se refiere el relato es el enorme templo dedicado al dios de la lluvia bajo la advocación de Chiconauhquiáhuitl ("Nueve-lluvia”). Este edificio,

6I. Edmundo O'Gorman, en sus notas de los Memoriales o Libro de las cosas de la Nueva España $y$ de los naturales de ella de fray Toribio de Motolinía Benavente (Edmundo O'Gorman, México, Universidad Nacional Autónoma de México-Instituto de Investigaciones Históricas, 197I, p. 84, n. 2), explica que, aunque es poco usual llamar "torre de Babilonia" a la torre de Babel, no existe error, puesto que ambos nombres son sinónimos, derivados del asirio Babili.

62. Motolinía, Memoriales, op. cit., p. 84. 
el mayor de Mesoamérica, se yergue como un monte en la actual ciudad de Cholula, y sobre él destaca el templo que erigió la religión vencedora, edificio dedicado a la Virgen de los Remedios, a quien ahora se imploran las lluvias. Así describió la pirámide Gabriel de Rojas en el siglo XVI, sin descuidar la mención a los frecuentes rayos, aunque explicando su golpe a partir de los conocimientos contemporáneos de la física:

En un cerro que hay en esta ciudad [...] en lo alto dél, en una ermita que allí tenían hecha, estaba un ídolo llamado Chiconauh Quiahuitr, que quiere decir "el que llueve nueve veces", porque al "llover" llaman QuiAhuitl y, al número de "nueve" dicen Chiconauhe. A es[e ídolo] hacían oración cuando tenían falta de agua, y le sacrificaban niños de edad de seis a diez a[ñ $]$ os que cautivaban y compraban para este efecto, porque éste era su abogado de las lluvias. ${ }^{63}$

Antes q[ue] los españoles ganaran esta tierra, no se remataba este cerro en llano, sino en forma convexa, y los religiosos lo hicieron allanar para poner allí aquella cruz, la cual, ha más de cuarenta años, fue dos veces derribada de rayos; donde los religiosos, pensando que había algún mist[eri]o en ello, hicieron cavar en lo alto del dicho cerro y hallaron muchos caracoles grandes marinos con que los indios antiguamente tañían en lugar de trompetas. Y, quien considera bien la naturaleza de los rayos, y que esta ciudad y comarca de ordin[ari]o caen muchos, no tendrá a milagro (como algunos historiadores quieren) el haber derribado dos veces aquella cruz, por estar, como está dicho, más alta que los más altos edificios de la ciudad [en] cuarenta varas. ${ }^{64}$

El mito del edificio roto también fue recogido por el capellán de Cortés, Francisco López de Gómara, quien lo registra con informes aclaratorios, entre ellos que la figura del anuro fue tenida por objeto sagrado. Sin embargo, López de Gómara confunde el templo cholulteca conocido como Tlachihualtépetl —ya en ruinas a la llegada de los españoles - con la gran pirámide de Quetzalcóatl, que estaba en uso en tiempos de la conquista:

El templo que comenzaron para Quezalcoatl [los cholultecas] era el mayor de toda la Nueva España, que, según cuentan, lo querían igualar con el cerrejón que llaman ellos Popocatepec, y con otros que, por tener siempre nieve, llaman Sierra Blanca.

63. Gabriel de Rojas, "Relación de Cholula”, en René Acuña (comp.), Relaciones geográficas del siglo XVI: Tlaxcala, México, Universidad Nacional Autónoma de México-Instituto de Investigaciones Antropológicas, 1984-I985, vol.II, p. I32.

64. Ibidem., p. I43. 
Querían ponerle su altar y estatua en la región del aire, pues le adoraban por dios de aquel elemento; empero no lo acabaron, a causa, según ellos mismos afirmaban, que edificando con la mayor prisa vino una grandísima tempestad de agua, truenos, relámpagos, y una piedra con figura de sapo. Les pareció que los dioses no consentían que aquél se aventajase en casa; y así cesaron. Aun así, quedó muy alto. Tuvieron de allí en adelante al sapo por dios, aunque lo comen; aquella piedra que dicen, la tenían por rayo: porque muchas veces, desde que son cristianos, han caído terribles rayos allí. ${ }^{65}$

Mucho más breve es la referencia de fray Diego de Durán. Sin embargo, el dominico identifica correctamente el edificio del relato al hablar de la portentosa ruptura:

En Cholula tenían un cerro hecho a mano, al cual, por ser hecho a mano, le llamaban Tlachibualtepetl, que es lo mesmo que "cerro hecho a mano". Llamábanle así, porque dicen que fue el cerro que los gigantes edificaron para subir al cielo, el cual (cerro) está agora en medio desbaratado. A este cerro tenían en mucho y en él era la ordinaria y continua adoración que hacían, y plegarias y grandes sacrificios y ofrendas y muertes de hombres. ${ }^{66}$

El nombre del templo del prodigio, Tlachihualtépetl, pasó a ser uno más de los apelativos dados a la ciudad santa, también conocida como Tollan Cholollan, ${ }^{67}$ nombre este último que la convierte en una réplica de la ciudad anecuménica en que habitaron todos los grupos humanos antes de salir a la superficie de la tierra. ${ }^{68}$

Como muchos otros relatos míticos mesoamericanos, la ruptura de la pirámide de Cholula rememora narraciones de otras mitologías del mundo, y el mismo Motolinía se encarga de señalar la semejanza de aquella obra interrumpida

65. Francisco López de Gómara, Historia general de las Indias, 2a. parte, Conquista de México, Barcelona, Orbis, I985, p. 327.

66. Diego Durán, Historia de las Indias de Nueva España e islas de Tierra Firme, 2a. ed., México, Porrúa, 1984, vol. I, p. 166.

67. Rojas, "Relación de Cholula", op. cit., p. I28; Diego Muñoz Camargo, Descripción de la ciudad y provincia de Tlaxcala de las Indias y del Mar Océano para el buen gobierno y ennoblecimiento dellas, ed. facs. del Manuscrito de Glasgow, René Acuña (ed.), México, Universidad Nacional Autónoma de México-Instituto de Investigaciones Filológicas, I98I, f. 85v.

68. Alfredo López Austin y Leonardo López Luján, Mito y realidad de Zuyuá. Serpiente Emplumada y las transformaciones mesoamericanas del Clásico al Posclásico, México, El Colegio de México / Fideicomiso Historia de las Américas / Fondo de Cultura Económica, 1999, pp. 86-93. 


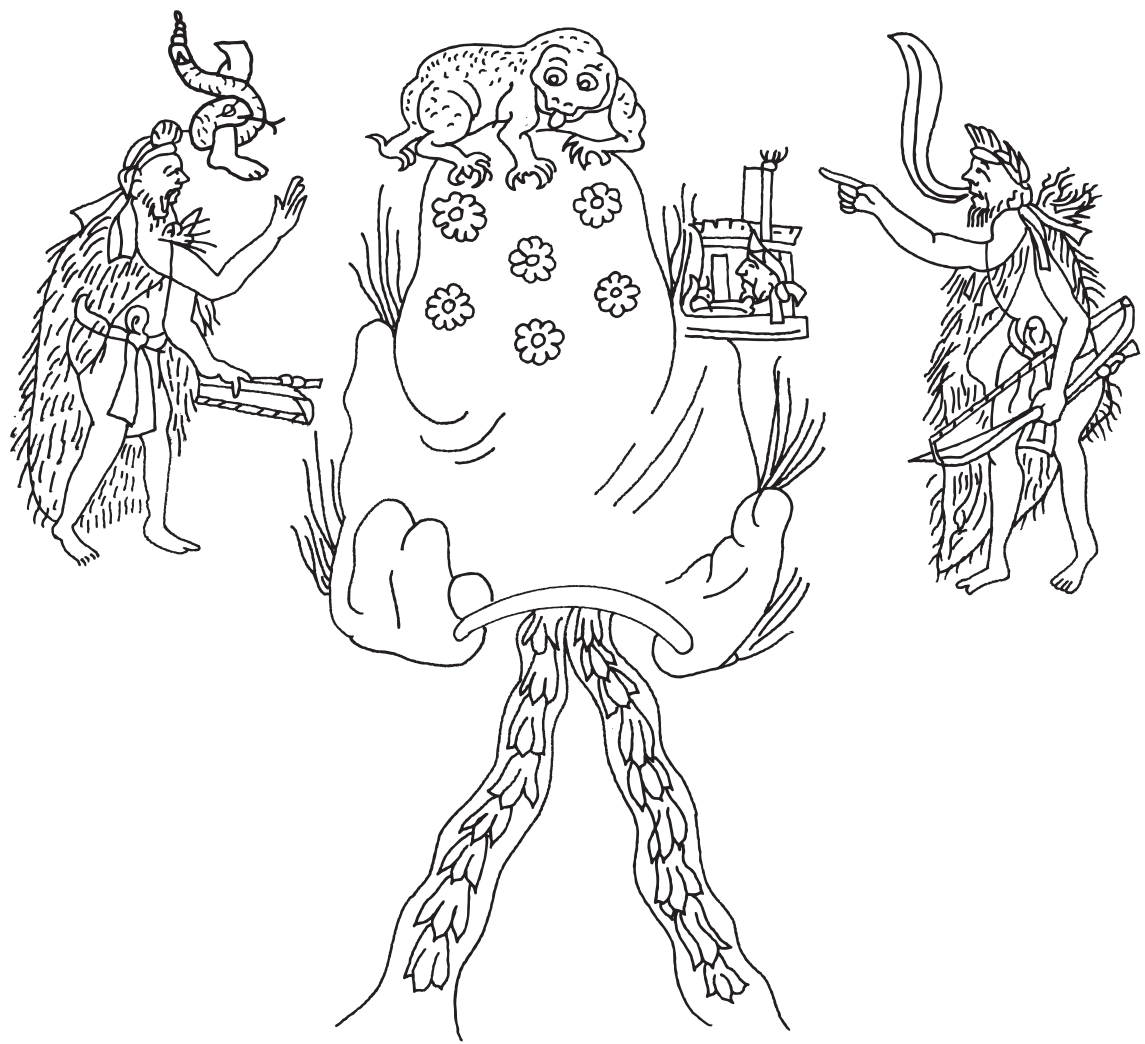

22. Símbolos de la ciudad de Cholula. Dibujo de Fernando Botas Vera basado en la Historia tolteca-chichimeca, Paul Kirchhoff et al. (eds.), México, Centro de Investigaciones Superiores y Estudios en Antropología Social/Instituto Nacional de Antropología e Historia/Secretaría de Educación Pública, 1976, f. 7v.

con la bíblica construcción de la Torre de Babel. Sin embargo, la originalidad del relato mesoamericano tiene suficientes apoyos. El primero es, obviamente, la tradición del sapo adorado por los cholultecas. El anuro, junto con el templo Tlachihualtépetl dedicado a la lluvia, es uno de los emblemas de la ciudad santa, y así puede observarse en el folio $7 \mathrm{v}$ de la Historia tolteca-chichimeca, donde la figura del sapo corona el cerro adornado con seis flores, flanqueado éste por los dos famosos gobernantes Icxicóatl y Quetzaltehuéyac (fig. 22). Similares representaciones aparecen en los folios 9v-Ior y I4r, donde el cerro se encuentra junto al tule blanco y el huejote blanco, elementos hierofánicos del milagro fundacional. 


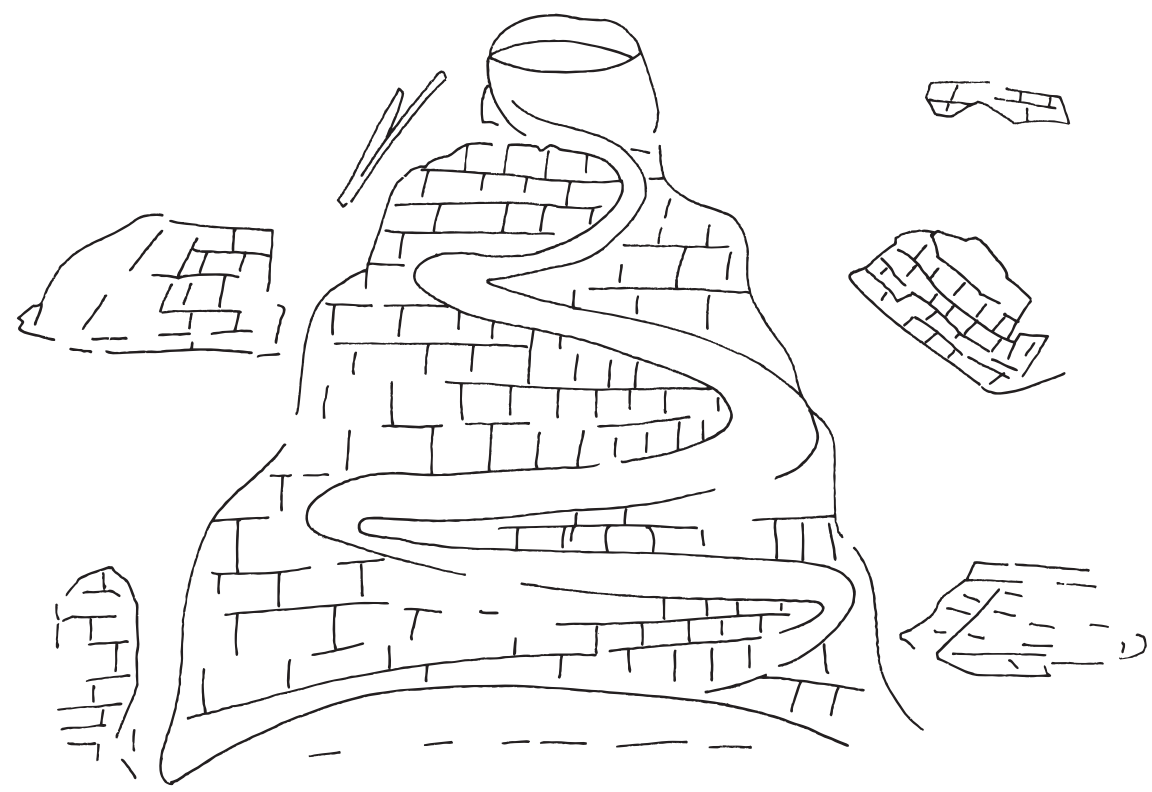

23. El Tlachihualtépetl roto. Dibujo de Fernando Botas Vera basado en El Códice de Cholula. La exaltación testimonial de un linaje indio, Francisco González-Hermosillo y Luis Reyes García (estudio, paleografía, traducción y notas), México, Instituto Nacional de Antropología e Historia/Gobierno del Estado de Puebla/Centro de Investigaciones y Estudios Superiores en Antropología Social/Grupo Editorial Miguel Ángel Porrúa, 2002.

El mito subsistió, cada vez más cubierto de elementos legendarios aportados por el cristianismo. El Códice de Cholula, un importante documento pictográfico cuya antigüedad se ubica entre finales del siglo xvi y la primera mitad del XVII ${ }^{69}$ nos ofrece la imagen del monte roto, rodeado de varios de los pedazos de su cúspide (fig. 23). Luis Reyes García paleografió y tradujo del náhuatl la glosa referente al milagro:

Aquí empezó estimado señor [...] Cholula que así esté vuestro corazón, aquí está doña maría espejo de vuestro señorío; verán como [...] que primero vinieron a

69. Rafael Loyola Díaz, "Casa señorial y linaje de Ylamateuhtli”, en El Códice de Cholula. La exaltación testimonial de un linaje indio, Francisco González-Hermosillo y Luis Reyes García (estudio, paleografía, traducción y notas), México, Instituto Nacional de Antropología e Historia/ Gobierno del Estado de Puebla/Centro de Investigaciones y Estudios Superiores en Antropología Social / Grupo Editorial Miguel Ángel Porrúa, 2002, p. I3. 
vivir los hombres largos gigantes que luego se perdieron, en todas partes hubo inundación... el Tloque Nahuaque dueño del cielo y de la tierra dios nuestro señor [...] creó a nuestros padres, a los pilli [...se salvaron con] Noé en una caja (canoa). Una vez que se desbarataron vinieron a construir la montaña de los tolteca, el Tlachihualtépetl, con adobes y con lodo [...] dijeron: si alguna vez de nuevo nos inundamos subiremos [...] otros dijeron, subiremos al cielo [...] sólo llegaban arriba del aire [...] año caña. Llegaban arriba del aire. El Tlachihualtépetl de los toltecas. Aquí nuestro padre San Miguel lo vino a desbaratar. Los hombres que vivían en las tinieblas lo vieron.

Fue a caer a los chichimecas

Fue a caer al mar

...nahuac

Fue a caer a Michuacan, "donde están los dueños de los pescados" año caña. ${ }^{70}$

Con la influencia cristiana, el enviado celestial que rompió el monte fue san Miguel arcángel. Su intervención no es casual. Los indígenas aceptaron la imagen del arcángel cubriéndola con los atributos de divinidad pluvial, y hasta hoy en muchas regiones del país se da su nombre a la persona del Rayo.

La tradición de la ruptura del gran promontorio no ha muerto a pesar del paso de los siglos. Ligia Rivera Domínguez ha recogido escrupulosamente, durante varios años, los relatos populares de Cholula y sus alrededores, y es de esperarse que muy pronto dé a conocer al menos parte del abundante acervo etnográfico. Entre los valiosos textos registrados por la investigadora se encuentran aún los de la ruptura de la gran montaña (san Miguel sigue apareciendo como el personaje que la fractura), narraciones donde se agrega que los pedazos resultantes cayeron para formar montañas menores. ${ }^{7 \mathrm{I}}$

¿A qué nos remite la narración del milagro cholulteca? En la historia de la ciudad santa — réplica terrenal de la Tollan anecuménica — se repite el arquetipo cósmico. En este caso el mito habla del don divino de la lluvia. Las aguas, encerradas primordialmente en el mundo de los dioses, en el gran vientre del Monte Sagrado, irrumpieron con violencia en el mundo de las criaturas. El Eje Cósmico se rompió, se liberaron las aguas y los rayos, y la figura de un anuro quedó sobre la tierra como el vocero de los dioses pluviales.

70. El Códice de Cholula, op. cit., pp. I2O-I2I.

7I. Comunicación personal. 
El mito de la ruptura del promontorio no debe ser considerado como una creencia exclusiva de la región poblano-tlaxcalteca. Por el contrario, narraciones similares aparecen hoy en día en otras partes del territorio que en un tiempo ocupó Mesoamérica, y es de suponer que con mucha mayor frecuencia debieron de haber aparecido en diversas ciudades de la antigüedad. El Monte Sagrado, como Eje Cósmico, se proyectaba en los montes que dominaban cada paisaje local. Los montes circundantes, menores, eran los fragmentos de la cúspide desgajada y, como en la actualidad, quedaban subordinados al monte principal en la jerarquía sagrada del paisaje. Al respecto nos dice fray Diego Durán:

En medio de esta pieza [del templo del Monte de Tlalocan], sentado en un estradillo, tenían al ídolo Tláloc, de piedra, a la manera que estaba en el templo de Huitzilopochtli. A la redonda de él había cantidad de idolillos pequeños, que lo tenían en medio, como a principal señor suyo, y estos idolillos significaban todos los demás cerros y quebradas que este gran cerro tenía a la redonda de sí. ${ }^{72}$

Hoy, $212 \mathrm{~km}$ al norte de la ciudad santa de Cholula, se encuentra la población veracruzana de Chicontépec ("en los siete montes"); en su horizonte sobresale el monte Postectli. Gómez Martínez, profundo conocedor de las creencias de la región, dice al respecto:

En cada una de las localidades de Chicontepec existen cerros epónimos donde se realizan rituales privados y comunitarios, pero colectivamente las comunidades reconocen siete montañas como espacios rituales cargados de mitología e historia, donde ubican su origen. Estos cerros se localizan al oeste del municipio de Chicontepec y se levantan como conos en un terreno poco escarpado, todos ellos alineados en torno a uno de mayor dimensión que alcanza una altura de 850 metros sobre el nivel del mar; se trata del santuario Postectli, también llamado Poctectitla o cerro de Ichcacuatitla. El vocablo Postectli significa "lugar donde se fragmentó la montaña". La etimología remite a los hechos míticos narrados por los indígenas donde se dice que en tiempos primigenios los dioses rompieron la montaña a causa de las malas acciones humanas; el tamaño del collado era tan grande que llegaba al cielo, uniendo los tres planos del universo: cielo, tierra e inframundo. Los primeros hombres de esta generación se aprovecharon de ella para subir al recinto celeste, robarse los comestibles sagrados y fisgonear las actividades de los dioses. Por estas razones las deidades lo fragmentaron en siete partes, cuyos restos cayeron esparcidos 
alrededor del macizo [...] En cada uno de ellos fueron instaladas las divinidades autóctonas. Estos cerros menores son considerados como hijos del Postectli. ${ }^{73}$

Aunque Gómez Martínez explica el significado de la palabra poztectli, en realidad interpreta más allá de la literalidad con el fin de exponer la creencia de base; pero poztectli quiere decir, en sentido estricto, "el roto". Su otro nombre, Ichcacuatitla, se puede traducir como "el lugar de la cabeza de algodón". Es muy probable que el segundo nombre aluda a su cumbre llena de nubes, idea vinculada a la naturaleza de los montes sagrados, generadores de las nubes y las lluvias.

Recorriendo el espacio, ahora hacia el occidente y a una distancia de $68 \mathrm{~km}$ de Chicontépec, ${ }^{74}$ ya en territorio huasteco, encontraremos otro ejemplo. Como sus vecinos nahuas, los huastecos mantienen la idea de la montaña rota que en la antigüedad mítica se elevaba hasta tocar el cielo. Hoy la llaman en lengua teenek Tidhoch, y recibe en español el nombre de "La Silleta". Este promontorio se ubica en el municipio de Xilitla, San Luis Potosí.75 En la mitología huasteca contemporánea la ruptura del Eje se reproduce en las cuatro proyecciones primigenias del axis mundi. Al final de cada año se quiebran los cargadores del cielo, produciendo un crujido como el de las ramas de un árbol que se rompe. Los seres dañados se van al paraíso y son sustituidos como soportes por otras cuatro personas investidas de la misión divina. ${ }^{76}$

\section{Elpatrono}

Insisto, entre los glifos toponímicos de la Piedra del Ex-Arzobispado y la Piedra de Tízoc, el glifo del anuro frente al monte roto destaca por una evidente diferencia: no se refiere en forma simple a un topónimo, pues la unión de sus dos

73. Arturo Gómez Martínez, "Culto a los cerros y espacio ritual en Chicontepec, Veracruz", en Johanna Broda y C. Good Eshelman (comps.), Historia y vida ceremonial en las comunidades mesoamericanas: los mitos agrícolas, México, Instituto Nacional de Antropología e Historia/ Universidad Nacional Autónoma de México, 2004, pp. 58-259.

74. Las distancias entre Cholula, Chicontépec y Xilitla han sido calculadas por Gerardo Jiménez Delgado.

75. Maelwits Fernández Esteban, "La vieja K’olene”, en Relatos huastecos. An tilabti tenek, México, Secretaría de Educación Pública (Lenguas de México, 4), 1994, p. 33.

76. Janis B. Alcorn, Huastec Mayan Ethnobotany, Austin, University of Texas Press, I984, p. 57. 
componentes conduce a la figura cósmica, arquetípica, de la ruptura del Eje, que se humaniza al convertirse en milagros fundacionales.

Ahora bien, ¿hay otros elementos en los dos monolitos que apoyen esta propuesta? Los especialistas han repetido que los guerreros vencidos son los dioses patronos de los pueblos conquistados. En las tallas de ambos monumentos el personaje capturado luce en su cabeza dos plumas blancas de garza, divisa denominada aztaxelli, propia de los guerreros; en ambas se cubre el torso con el ichcahuipilli, jubón de guerra, formado con una gruesa capa de algodón que detenía el golpe de las armas ofensivas; en ambas lleva el anáhuatl, colgante en forma de disco del que penden correas cuyos extremos están cortados en forma de colas de golondrina; en ambas tiene un máxtlatl liso, rectangular, aunque en la versión del monolito del Ex-Arzobispado la prenda muestra una orla simple y recta. En la Piedra de Tízoc, el personaje lleva sobre el pecho un collar ancho rematado por cascabeles redondos.

Tomemos con pinzas el aztaxelli: no caracteriza al personaje, ya que es común en los guerreros vencidos de estos monolitos. Del anáhuatl Seler sospechó que vinculaba al cautivo con Tezcatlipoca o con Tepeyóllotl. ${ }^{77}$ Esto pudiera proporcionar una pista. En un trabajo anterior he propuesto que Tepeyóllotl es la divinidad que personifica el conjunto de "semillas-corazones" o entidades invisibles que constituyen el "alma" de las riquezas depositadas en el interior del Monte Sagrado, las cuales salen a la superficie de la tierra como bienes donados a los hombres. ${ }^{78}$ Un pueblo que tuviera como mito fundacional la ruptura del Monte Sagrado y el desbordamiento de sus riquezas bien pudo reconocer como dios patrono a Tepeyóllotl. Si se toma en cuenta la más bella representación de este dios, la del Códice borbónico (fig. 24), ${ }^{79}$ se encontrará que está vestido con piel de jaguar, adornado con el aztaxelli, cubierto por un máxtlatl blanco, liso, apenas orlado por una banda lisa y recta. Lleva sobre su pecho un collar ancho del que penden cascabeles redondos. Su divisa principal es el gran anábuatlcon sus correspondientes colgantes cortados como cola de golondrina. En cuanto al ichcahuipilli, pese a que el dios está cubierto con la piel del jaguar, muestra sobre el muslo derecho la franja decorada de la parte inferior del jubón.

77. Seler, op. cit., pp. 134-136.

78. López Austin, Tamoanchan y Tlalocan, México, Fondo de Cultura Económica, 1994, p. 186.

79. Códice borbónico, ed. facs., México / Graz, Fondo de Cultura Económica / Sociedad Estatal Quinto Centenario/Akademische Druck- u. Verlagsanstalt, I99I, lám. 3. 
Pese a todo lo anterior, debe reconocerse que las similitudes entre Tepeyóllotl y el guerrero vencido no son concluyentes. Así, el anáhuatl, la importantísima divisa que porta en el pecho, puede aparecer en imágenes de otros muchos dioses, aparte de los dos mencionados.

\section{La atribución de un topónimo}

En 1949 apareció una obra seminal para el estudio de la organización política del Posclásico mesoamericano, y en particular para la composición de los dominios mexica-tenochcas: el libro de Robert H. Barlow, The Extent of the Empire of the Culhua Mexica. ${ }^{80}$ Muy poco después, en 1952, y con el interés particular de estudiar las conquistas de los mexicas y sus aliados en el Totonacapan, Kelly y Palerm publicaron su clásico trabajo The Tajin Totonac. Otros esfuerzos meritorios se realizaron durante décadas; pero el nuevo impulso en los estudios sobre el tema no se dio hasta mediados de los noventa con los libros de Ross Hassig, Aztec Warfare; Pedro Carrasco, Estructura político-territorial del imperio tenochca, y Frances F. Berdan y otros, Aztec Imperial Strategies, este último con muy puntuales precisiones de esa autora y de Smith en lo que toca a las correlaciones de fuentes documentales y pictográficas para determinar las conquistas de la Triple Alianza.

Aunque las investigaciones mencionadas son un fuerte jalón para comprender la organización política de la Triple Alianza y sus dominios, el asunto sigue siendo sumamente complejo, y subsiste la duda sobre el alcance de las fuentes. Hanns Prem, por ejemplo, sostiene que las listas de tributos y conquistas son insuficientes e inadecuadas para definir los alcances del imperio, por lo cual, a su juicio, la extensión del territorio dominado por la Triple Alianza empieza a disolverse en unidades cuyo carácter resulta poco transparente. ${ }^{8 \mathrm{I}}$ En cuanto a los glifos toponímicos, dice que "es bien claro [...] que muchos jeroglíficos nahuas permiten lecturas varias, de las cuales en un caso concreto sólo una podría ser la

8o. Recientemente, Monjarás-Ruiz, Limón y Paillés han hecho muy accesible este libro en su versión española, Robert H. Barlow, La extensión del imperio de los culhua mexica, México, Instituto Nacional de Antropología e Historia/ Universidad de las Américas, 1992.

8I. Hanns Prem, "La extensión del dominio mexica", en Constanza Vega Sosa (comp.), Códices $y$ documentos sobre México. Tercer Simposio Internacional, México, Instituto Nacional de Antropología e Historia, 2000, p. 6I2. 
24. Tepeyóllotl. Dibujo de Fernando Botas Vera basado en el Códice borbónico, ed. facs., México/

Graz, Fondo de Cultura Económico/Sociedad

Estatal Quinto Centenario/Akademische

Druck- u. Verlagsanstalt, lám. 3, I99I.

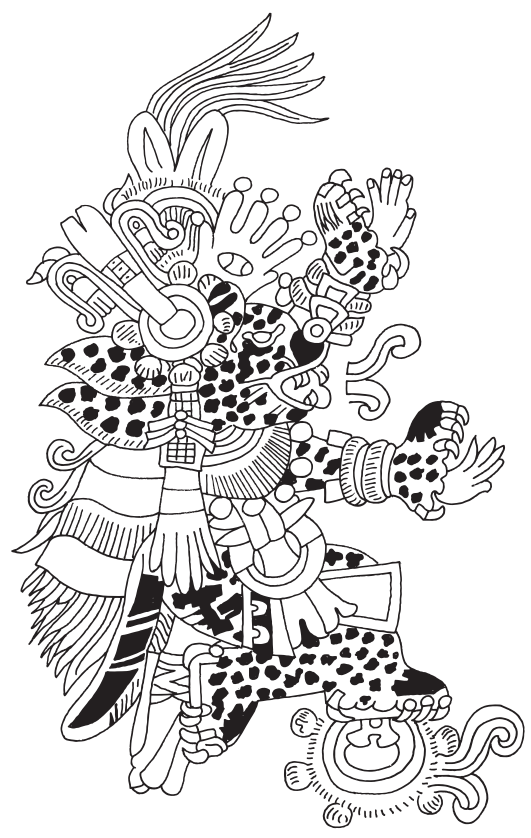

correcta, la que su autor tuvo la intención de manifestar", y que "esta imprecisión se debía a las dificultades de expresar nombres por representaciones gráficas que casi inevitablemente tienen que resultar ambiguas". ${ }^{82}$

La vinculación de un glifo toponímico — en su caso el del anuro frente al monte roto-y un topónimo que corresponda a una de las conquistas mexicas está muy lejos, por tanto, de la simplicidad de un mero ajuste etimológico. Sin embargo, y aunque éste no es el problema que me propuse resolver en el presente trabajo, hago algunas puntualizaciones.

I. La identificación plena del animal como un anuro descarta que el glifo pueda adjudicarse a Xaltocan o a Azcapotzalco.

2. Son muy escasas las probabilidades de que, aparte del caso cholulteca, haya quedado registro preciso en las fuentes documentales de un relato mítico o milagroso que sirva de base para identificar el topónimo.

3. Hipotéticamente la atribución del glifo a un lugar conquistado por los mexicas abre tres líneas de investigación: 
a) el topónimo se refiere a un anuro como derivación del mito de la ruptura del Eje, haciéndolo implícito;

b) el topónimo alude al monte roto, con igual respaldo;

c) el glifo se refiere al mito o al milagro, pero sin relación directa con el topónimo del lugar conquistado; el glifo opera al sobreentenderse el relato del prodigio y el topónimo.

Con escasos recursos de las fuentes, juguemos con posibilidades de atribución, más como ejemplos que como propuestas.

La referencia al anuro se cumple en Tamazollan y Tamazulapan. Tamazollan o Tamazolla pertenece a la Mixteca Alta y es cercano al actual Santiago Tilantongo. Según Bazán, su nombre mixteco era Nuyagua ${ }^{8}{ }^{8}$ que René Acuña traduce como "pueblo de ranas". ${ }^{84}$ En el pueblo se hablaba mixteco y chocho, y fue conquistado por Motecuhzoma Ilhuicamina. ${ }^{85}$ En el Códice mendocino y en la Matrícula de tributos es uno de los pueblos que pagan tributos con Coaixtlahuaca. ${ }^{86}$ Según la leyenda de su dinastía, su primer gobernante descendió del cielo y su consorte nació de una piedra que se abrió. ${ }^{87}$ En su geografía sagrada se menciona una montaña llamada Nuñañu en mixteco, Tlacotépec en náhuatl y Peña Tajada en español. ${ }^{88}$ Acuña traduce Nu Nañu, Nu Tzàun o Nu Tnañu como "en el cerro tajado" o "en la media montaña". ${ }^{89}$ Sus habitantes usaban el ichcahuipilli, descrito como "manta estofada con algodón". ${ }^{90}$

Tamazulapan —el actual Tamazulapan del Progreso- no es tan buen candidato. Se encuentra en la lámina del Códice mendocino en que aparece Tamazollan. ${ }^{91}$ Pertenece también a la Mixteca Alta. En el pueblo se hablaba mix-

83. Juan de Bazán, "Relación de Tilantongo y su partido", en Relaciones geográficas, op. cit., p. 228.

84. Acuña, en Bazán, ibidem, p. 228, n. 4.

85. Ross Hassig, Aztec Warfare. Imperial Expansion and Political Control, Londres, Norman / University of Oklahoma Press, 1995, p. 173. Michael E. Smith y Frances F. Berdan, "Province Descriptions [Appenndix 4], en Aztec Imperial Strategies, Washington, Dumbarton Oaks Research Library and Collection, 1996, pp. 28I y 282.

86. Codex Mendoza, op. cit., f. 43r, véase Matrícula de tributos, María Teresa Sepúlveda (interpretación y análisis), Miguel León-Portilla (introd.), historia de la Matrícula de Víctor M. Castillo Farreras, Arqueología Mexicana (edición especial 4), 2003, lám. 23.

87. Bazán, op. cit., p. 244.

88. Ibidem, p. 246.

89. Acuña, en Bazán, op. cit., p. 246, n. 59.

90. Bazán, ibidem, p. 245.

91. Codex Mendoza, op. cit., f. 43r. Véase Matrícula de tributos, op. cit., lám. 23. 
teco y chocho. Fue conquistado por Motecuhzoma Ilhuicamina. ${ }^{92}$ Durante la colonia perteneció a Texupa. ${ }^{93} \mathrm{Su}$ gente peleaba en la guerra con "unos coseletes hechos de algodón, colchados, a manera de coracinas hasta el ombligo". ${ }^{94}$

Para la segunda línea de investigación se tiene en la lista de conquistas mexicas un pueblo denominado Poztectlan ("El lugar del roto"), ${ }^{95}$ nombre muy cercano al del actual Postectli del que nos habla Arturo Gómez Martínez. El antiguo Poztectlan se llama hoy Poxtitlán, ${ }^{96}$ y está en la parte meridional y serrana del Totonacapan. Perteneció en la antigüedad a Misantla y hoy se encuentra en su municipio, al norte de Xalapa. No es fácil creer que la conquista de un pueblo de tan poca importancia quedara registrada como una gran conquista en los dos monolitos mexicas; pero hay la posibilidad de que el nombre se refiriera a Misantla misma. Hay que tomar en cuenta que las poblaciones mesoamericanas de la antigüedad tenían varios nombres, en parte debido a las diferencias lingüísticas interregionales. También es posible que el pequeño pueblo de Poztectlan hubiese sido designado con uno de los nombres de su centro político, muy cercano a él. Por otra parte, ¿cómo pudo haberse representado glíficamente el topónimo de Misantla? No hay una idea clara. En primer lugar, no se sabe si Misantla es una palabra totonaca, pues hoy es irreconocible; en segundo, todos los esfuerzos por interpretarla como palabra náhuatl o de vincularla a un glifo que justifique dicho origen ${ }^{97}$ es un juego malabar.

¿Cuál de las fuerzas de la Triple Alianza conquistó Misantla, y cuándo ocurrió la conquista? Ramírez Lavoignet propone que el vencedor de Misantla fue Axayácatl, tlatoani de México-Tenochtitlan, en una campaña en que sería

92. Smith y Berdan, op. cit., pp. 28I-282.

93. Diego de Avendaño, "Relación de Texupa", en Relaciones geográficas..., op. cit., p. 220.

94. Ibidem, p. 220.

95. Smith y Berdan, op. cit, p. 306.

96. David Ramírez Lavoignet, en Diego Pérez de Arteaga, Relación de Misantla, notas de David Ramírez Lavoignet, Xalapa, Universidad Veracruzana, 1962, p. I24.

97. Pérez de Arteaga, op. cit., p. I3; Ramírez Lavoignet, en Pérez de Arteaga, "Notas históricas de Misantla”, op. cit., pp. 23-26; Ignacio Bernal y Eusebio Dávalos Hurtado (comps.), Huastecos, totonacos y sus vecinos, México, Sociedad Mexicana de Antropología, I953, pp. 328-329. Ramírez Lavoignet se apoya para su análisis filológico en los datos del propio Pérez de Arteaga, en Muñoz Camargo, op. cit., y en el Códice Misantla (véase Ramón Mena, "Códice 'Misantla' publicado e interpretado", Société Scientifique Antonio Alzate, t. 30, I9I9-I9II, pp. 389-395), para concluir que el origen es Mazatlan; pero sus derivaciones y consideraciones son más complejas de lo que exige la claridad explicativa de un topónimo. 
derrotada Xalapa, y que la fecha fue $1480 .{ }^{98} \mathrm{Ni}$ el dibujo del Códice Misantla ni la Relación de Xalapa — fuentes en que David Ramírez Lavoignet se apoya - parecen suficientes para sostener su argumentación ni en cuanto a conquistador ni en cuanto a fecha. ${ }^{99}$ Sin mencionar Misantla, Fernando de Alva Ixtlilxóchitl relata que Nezahualpilli, tlatoani de Tetzcoco, derrotó a los totonacos de la región de Nauhtla en I486, ${ }^{100}$ lo que corrobora Dibble al interpretar el Códice en cruz. ${ }^{\text {IOI }}$ Michael E. Smith y Berdan dicen que Misantla pudo haber sido conquistada por Axayácatl o por Nezahualpilli, pero se basan sólo en los autores mencionados. ${ }^{\mathrm{IO} 2}$ Por último, la Relación de Misantla informa que los misantecos entregaban tributo a Motecuhzoma Xocoyotzin. ${ }^{\text {I03 }}$

El escabroso territorio de Misantla es idóneo para percibir un paisaje mítico. La serranía de Chiconquiaco ("lugar de siete-lluvias") pudiera apuntar al culto de la diosa del agua, Chalchiuhtlicue; ${ }^{\text {IO4 }}$ existe en sus cercanías un pueblo llamado Tlalocan; Colipa ("sobre el torcido"), sitio próximo, rememora el cerro torcido que da nombre a Colhuacan; entre Misantla y Chiconquiaco queda la Sierra del Algodón —recuérdese el nombre Ichcacuatitla, sinónimo del actual Postectitla de Chicontépec_-; existe un río llamado en lengua totonaca Palpoala ("río de sapos") y, sobre todo, hay un monte al que se llama Cerro Quebrado, que en náhuatl tiene por nombre Quetzaltépetl ("monte precioso"). ${ }^{\text {IO5 }}$ Ramírez Lavoignet proporciona otra referencia a los anuros, las figuras verdes que aparecen en el Códice Misantla; ${ }^{106}$ pero una de las figuras parece lagartija y la composición del códice no da para una interpretación segura.

98. Ramírez Lavoignet, "Notas históricas...”, op. cit., p. 317.

99. Véanse Mena, "Códice 'Misantla' publicado e interpretado", op. cit., y Bravo de Lagunas, op. cit., p. 346.

ıoo. Fernando de Alva Ixtlilxóchitl, Historia de la nación chichimeca, en Obras históricas, México, Universidad Nacional Autónoma de México-Instituto de Investigaciones Históricas, 1975-1977, vol.II, p. I55.

ıоr. Dibble, Códice en cruz, México, Talleres Linotipográficos Numancia, 1942, pp. 69-70.

IO2. Smith y Berdan, op. cit., p. 306.

I03. Pérez de Arteaga, op. cit., p. I6.

I04. Véase la posible relación de la fecha chicomequiáhuitl con la diosa Chalchiuhtlicue en Alfonso Caso, Los calendarios prehispánicos, México, Universidad Nacional Autónoma de MéxicoInstituto de Investigaciones Históricas, p. 198.

I05. Ramírez Lavoignet, en Pérez de Arteaga, Códice de Misantla, op. cit., pp. 39-4I y I24, y

"Notas históricas de Misantla", op. cit., pp. 330-33I.

I06. Ramírez Lavoignet, en Pérez de Arteaga, op. cit., p. I3I, y "Notas históricas de Misantla", op. cit., p. 316. 
Por último, queda la referencia a los ichcahuipilli. Según su Relación, la gente de Misantla no usaba estas prendas defensivas porque no era un pueblo guerrero; pero las fabricaba para sus vecinos: "Dicen que nunca tuvieron guerra, y así no peleaban, sino hacían en este pueblo unos juboncillos estofados de algodón que iban a vender a tierra de guerra". ${ }^{\text {I07 }}$

Como tercera línea de investigación se señaló la posibilidad de que el glifo se refiriera al mito o al milagro, aunque sin relación directa con el topónimo. Ningún ejemplo es mejor que Cholula. La ciudad santa jamás fue conquistada por los mexicas, pero Gabriel de Rojas afirma que sus habitantes tenían guerra contra los de Huexotzinco, México y Tepeyácac. ${ }^{108}$ Los cholultecas se enfrentaron a la Triple Alianza al menos en una ocasión. Según Alvarado Tezozómoc, los tlatoque de la Triple Alianza se lanzaron en campaña para sofocar la rebelión de los de Ahuilizapan, Cuetlaxtlan y Cempoalla, quienes habían sido incitados a la guerra por Tlaxcala. Los aliados vencieron a los rebeldes, y en la derrota influyó, según Alvarado Tezozómoc, la falta de ayuda de los tlaxcaltecas a los

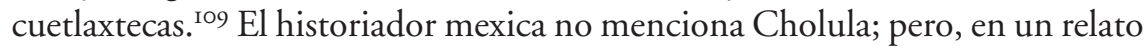
tardío, fray Juan de Torquemada hace referencia a esta campaña, incluyendo a huexotzincas y cholultecas tanto en la intriga como en la participación militar. Según él, los cholultecas llevaron consigo "a su dios Quetzalcóhuatl, porque como siempre les hablaba el demonio por boca de este ídolo, quisiéronlo tener cerca para saber en todas ocasiones lo que mejor les estuviese y debiesen hacer". ${ }^{\text {Io }}$ Según el franciscano, al enterarse los ejércitos aliados del poder numérico de sus adversarios, no se decidían a atacar; pero Moquíhuix, al frente de los mexica-tlatelolcas, se arrojó heroicamente contra los enemigos, causando su derrota, sin que a los cholultecas valiera "su falso dios Quetzalcóhuatl”. ${ }^{\text {III }}$

¿Hasta qué punto pudo haber valido la derrota de los cholultecas para registrar los acontecimientos en los dos monolitos mexicas? Indudablemente era motivo de enorme orgullo haber derrotado a un pueblo con tan grande protec-

I07. Pérez de Arteaga, op. cit., p. I7.

I08. Rojas, op. cit., p. I33. Véase también Durán, op. cit., pp. 178-183.

I09. Hernando de Alvarado Tezozómoc, Crónica mexicana, Gonzalo Díaz Migoyo y Germán Vázquez Chamorro (eds.), Madrid, Dastin, 200I, pp. I62-I65.

IIo. Fray Juan de Torquemada, Monarquía indiana. De los veinte y un libros rituales y monarquía indiana, con el origen y guerras de los indios occidentales, de sus poblazones, descubrimiento, conquista, conversión y otras cosas maravillosas de la mesma tierra, México, Universidad Nacional Autónoma de México-Instituto de Investigaciones Históricas, I975-I983, vol. I, p. 224.

III. Ibidem, p. 225. 
ción divina; pero también lo hubiera sido derrotar a los tlaxcaltecas, y esto no quedó registrado en las enormes esculturas. Además, es extraño que Alvarado Tezozómoc, proclive a exaltar la gloria de Mexico-Tenochtitlan, no mencione la participación de Cholula en esta guerra, omisión en la que pudo influir el hecho de que fueron los mexica-tlatelolcas y no los mexica-tenochcas quienes se llevaron la gloria.

En resumen, ni Tamazollan ni Tamazulapan tienen la importancia de Coaixtlahuaca, cuya conquista, en todo caso, hubiese quedado grabada en los monolitos; la atribución a Misantla es demasiado rebuscada como para tenerla por buena; la de Cholula sería, en el mejor de los casos, excepcional: la de un pueblo derrotado que no fue ni conquistado ni tributario. Sin embargo, creo que las tres líneas propuestas pueden ser utilizadas heurísticamente por quien pretenda resolver lo que sigue siendo un misterio. \$

N.B. Se agradece al dibujante Arturo Reséndiz el haber trazado nuevamente las figuras IO, II, I3, I5, I6, 20 y 2 I. 